THAIS DA COSTA PEREIRA

\title{
O CRIME ORGANIZADO TRANSNACIONAL E O TRÁFICO DE DROGAS NO MÉXICO
}

Trabalho de Conclusão do Curso de Pós Graduação em Relações Internacionais para a Universidade de Brasília, apresentado como requisito para obtenção do título de Especialista em Relações Internacionais. 
THAIS DA COSTA PEREIRA

\section{O CRIME ORGANIZADO TRANSNACIONAL E O TRÁFICO DE DROGAS NO MÉXICO}

Trabalho de Conclusão do Curso de Pós Graduação em Relações Internacionais para a Universidade de Brasília, apresentado como requisito para obtenção do título de Especialista em Relações Internacionais.

Orientador: Prof. Dr. Virgílio Caixeta Arraes

Brasília

2010 
PEREIRA, Thais da Costa

O Crime Organizado Transnacional e o tráfico de drogas no México / Thais da Costa Pereira, Orientador: Prof. Dr. Virgílio Caixeta Arraes - Brasília , 2010

$58 \mathrm{p}$.

Trabalho de Conclusão de Curso - Instituto de Relações Internacionais Universidade de Brasília - Curso de Especialização em Relações Internacionais.

1. Crime Organizado Transnacional 2. Tráfico de Drogas

3. México

I. Instituto de Relações Internacionais da UnB. II. Título

CDD - 


\section{RESUMO}

Este trabalho tem como seu objetivo a análise do crime organizado transnacional como um fenômeno que atualmente movimenta a sociedade e que dá forma às relações entre os Estados. A pesquisa traz também uma definição do que é o termo 'crime organizado' assim como sua tipologia. Demonstra como a atividade das organizações criminosas obtém grande influência, principalmente através do tráfico de drogas, interferindo na economia, política e no desenvolvimento social dos Estados. O estudo ainda identifica algumas das mais ativas redes criminosas que atuam no mundo moderno, com especial destaque para o México, mostrando como sua realidade econômica é afetada pelas organizações criminosas atuantes e seus modos de operação. 


\begin{abstract}
This paper offers an analysis of the transnational organized crime as a phenomenon which is an actual player that drives society and gives shape to relations between states. This research also brings a definition of the term "organized crime" as well its typology. It demonstrates how the organized crime syndicates manage to earn such great influence, mainly through drug trafficking operations, which interfere in the economy, politics and the social development of affected states. This study also identifies some of the most active criminal networks of the modern world, with a special highlight to Mexico, showing how its economy is struck by present crime syndicates and their ways of operating.
\end{abstract}




\section{SUMÁRIO}

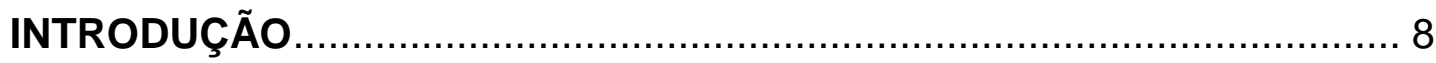

1. ORIGENS E DEFINIÇÃO DO CRIME ORGANIZADO .......................... 10

1.1 - Tipologia de atividades criminosas transnacionais ................................. 13

1.1 .1 - Tráfico de drogas ................................................................................ 13

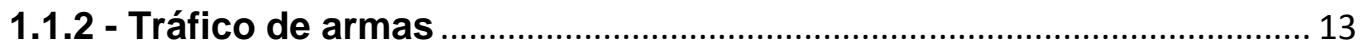

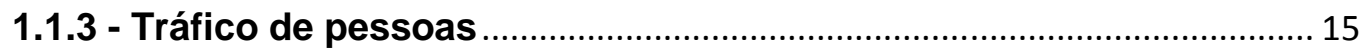

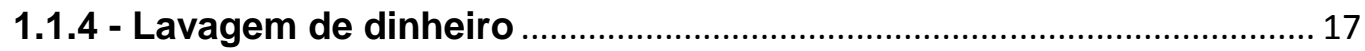

1.1.5 - Contrabando de imigrantes ilegais................................................... 19

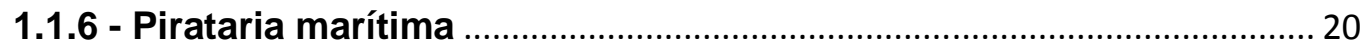

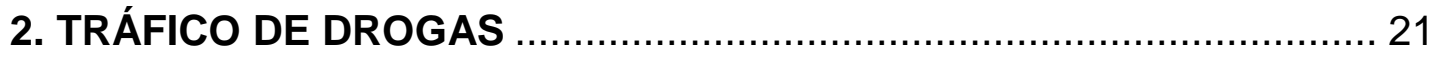

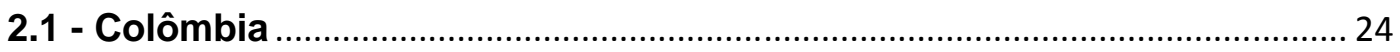

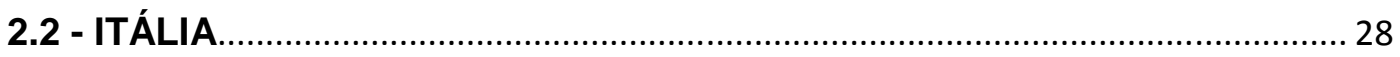

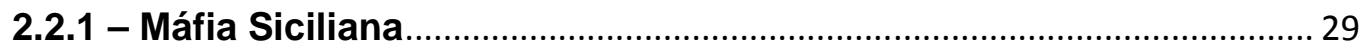

2.2.2 - Camorra

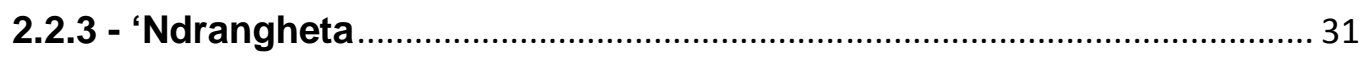

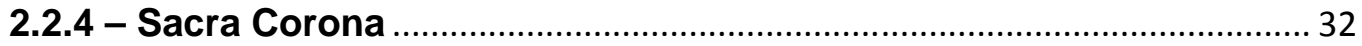

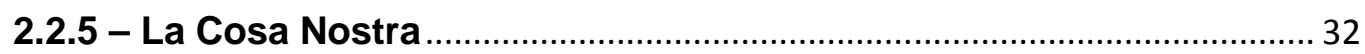

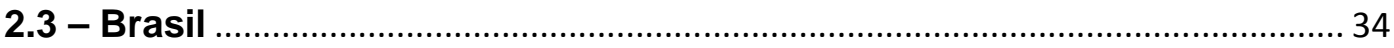

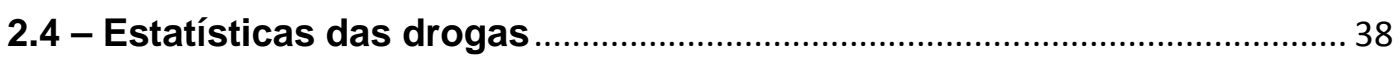

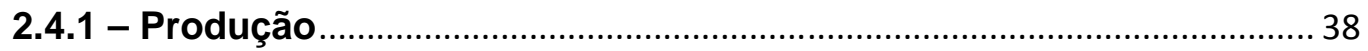

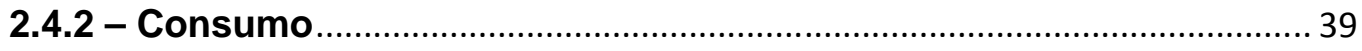

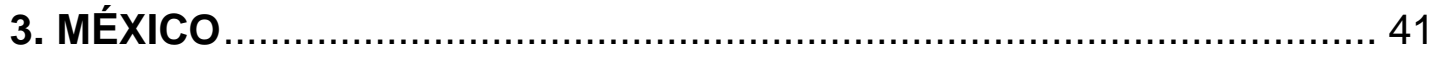

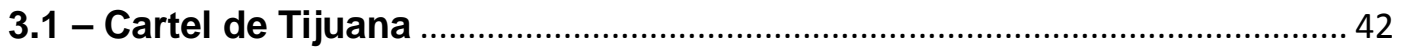

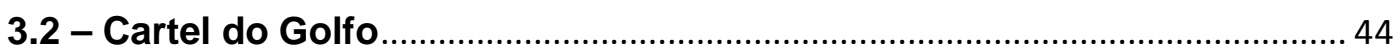

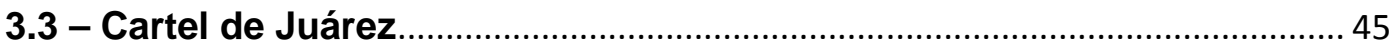

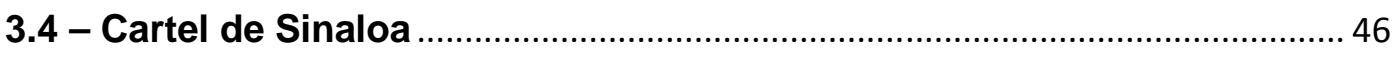

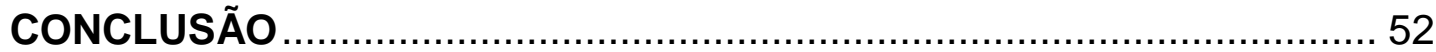




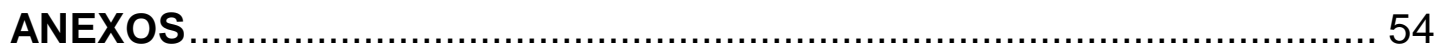

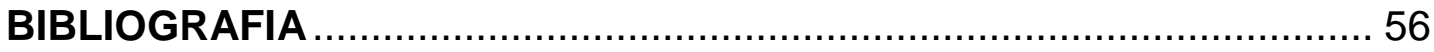




\section{INTRODUÇÃO}

No fim do último século, o mundo sofreu intensas mudanças, entre elas, o enorme avanço da tecnologia e dos meios de transporte. Tal facilidade de locomoção e comunicação mudou drasticamente a interação dos países. Entre tantos avanços, houve também mudanças na forma de agir dos agentes do crime organizado, que passaram a ter um impacto cada vez mais transnacional.

Em todos os continentes, o crime organizado se reformulou e se modernizou, pois nos dias de hoje, dificilmente há apenas um grande chefe que comanda os demais - como ocorriam antigamente em redes de máfias, como a italiana. O crime transnacional ocorre visando tráfico de drogas, armas, pessoas e animais silvestres, apenas para citar alguns, e combatê-lo não é tarefa fácil, exigindo muito dos governos e de suas polícias.

Nos Estados Unidos e no México não foi diferente. O problema do crime organizado no país latino tem aumentado bastante e a situação está crítica, com altos índices de violência. Juntamente a Colômbia, Peru e Bolívia, o México enfrenta um sério problema no controle e contenção das ações dos criminosos, visto que o México é um importante produtor de drogas e território de passagem para distribuição nos Estados Unidos, que é um grande consumidor.

Deste modo, o presente trabalho tem como objetivo estudar e analisar o crime organizado transnacional, com destaque para o tráfico de drogas no México, pois esse fenômeno sofreu diversas mudanças desde os primórdios da sua existência até os dias de hoje, principalmente na era pós-capitalista.

Os cartéis de drogas movimentam milhões de dólares por ano, tendo como grande receita a venda de drogas como cocaína, maconha, heroína e anfetamina. E para tal, essas organizações se utilizam da violência, sequestro, suborno, extorsão e corrupção. Vários grupos serão analisados com mais profundidade no decorrer deste trabalho. 
A fundamentação do estudo é baseada em autores que trabalham esta interface do crime organizado transnacional e seus efeitos dentro dos Estados e nas Relações Internacionais.

A metodologia utilizada é a análise do crime organizado de modo geral e o conceito em si, como também sua tipologia. Parte-se de uma breve discussão acerca de sua terminologia e atuação. Em seguida é feito um breve demonstrativo de algumas importantes organizações criminosas, tendo logo em seguida uma sucinta apresentação histórica do México e seus cartéis de drogas. Como base principal, foi feita uma pesquisa bibliográfica sobre como os criminosos influenciam no desenvolvimento econômico, social e político dos Estados.

O estudo está dividido em três capítulos, sendo mostrado, a princípio, uma discussão do conceito de crime organizado transnacional e alguns exemplos; em seguida o estudo do tráfico de drogas e sua movimentação em países como Colômbia, Itália e Brasil, além de apresentar alguns dados estatísticos da produção e consumo de drogas; e por fim faz-se uma análise mais detalhada da situação econômica e da atuação do crime no México, como também demonstração dos principais cartéis. 


\section{ORIGENS E DEFINIÇÃO DO CRIME ORGANIZADO}

Um ponto importante a ser levantado é sobre a definição de crime organizado, e a partir de que ponto é considerado um crime transnacional ou não. Segundo Adriano Oliveira, é muito importante descobrir quais são as características que podem definir um grupo de indivíduos que pratica atos ilícitos, como organização criminosa. Alguns pontos que devem ser observados: o modus operandi, as estruturas de sustentação e ramificação do grupo, as divisões de tarefas e seu tempo de existência. Um fator importante são suas dimensões de atuação, ou seja, existem organizações que atuam apenas em nível local, outras em âmbito nacional e por fim, no cenário internacional. ${ }^{1}$

É importante destacar que, nem todas atividades do crime organizado transnacional são praticadas por organizações criminosas, e nem tampouco, que toda organização criminosa se dedica ao crime transnacional. Entendese por transnacional, em sua definição mais simples, é algo que vai além das fronteiras nacionais, englobando mais de um país, cujo movimento pode ser de objetos físicos, dinheiro, informações e pessoas.

Segundo Donald R. Cressey, o crime organizado "é uma organização voltada para a maximização dos lucros com a venda de bens e serviços ilícitos, tendo a intenção criminosa como elemento definidor da estrutura do crime organizado"2. Ainda segundo este autor, o crime organizado apresenta algumas características importantes: organização totalitária; busca da imunidade e da proteção da lei pela corrupção; permanência; atividades lucrativas de risco relativo; uso de medo contra as vítimas e sócio; da chantagem contra os sócios públicos; contínuo ataque ao poder legal constituído; isolamento dos líderes; e disciplina rígida e hierarquia de graus. ${ }^{3}$

\footnotetext{
${ }^{1}$ OLIVEIRA, Adriano. Crime Organizado: é possível definer? Disponível em: $<$ http://www.espacoacademico.com.br/034/34coliveira.htm>. Acesso em: 24/02/2010.

2 CRESSEY, Donald R. Theft of the Nation: The Structure and Operations Of Organized Crime in America. New York: Harper, 1969. Apud: WERNER, Guilherme Cunha. O Crime OrganizadoTransnacional e as Redes Criminosas: Presença e Influência nas Relações Internacionais Contemporâneas. São Paulo: Universidade de São Paulo, 2009. p. 38.

${ }^{3}$ Ibidem, p. 38
} 
O crime organizado transnacional pode ser definido como a manifestação de organizações criminosas que apresentam algumas características: é composta por duas ou mais pessoas; atuam por um certo período de tempo; especialização e distribuição específica de tarefas, visando o aperfeiçoamento; sua motivação é a busca pelo ganho ilícito e poder; hierarquia vertical; normas e regras pré-estabelecidas, como qualquer organização; e ultrapassa as fronteiras, envolvendo mais de uma nação, tanto seu planejamento ou execução. Pode ocorrer de um indivíduo, usando a rede mundial de computadores, consiga aplicar golpes e fraudes, principalmente à instituições financeiras, adquirindo assim ganho ilícito, entretanto tal atividade não se enquadra como uma atuação de crime organizado transnacional.

Para Dennis Kanney e James Finckenauer, a pirataria representa uma manifestação original e primitiva do crime organizado, pois apresenta semelhanças com grupos que atuam no crime organizado, tais como: a organização hierárquica, a perpetuação, o cunho não ideológico, a violência, quadro selecionado de membros, busca de lucros a partir de atividades ilícitas, corrupção e demanda do público pelas suas mercadorias e seu comércio. ${ }^{4}$ Segundo Ana Luiza Ferro, "a promoção e o auxílio que comerciantes dedicavam aos piratas e a habilidade destes de comprar imunidade e 'legitimidade' de autoridades públicas os transformaram em um sistema integrado de comércio internacional."

Uma outra exemplificação de crime organizado é o que ocorreu em Nova York no final do século XIX, aproximadamente um século depois dos piratas, um clima de caos e grande pobreza, provavelmente facilitou a prática de grupos a atos ilegais, apesar de que contaram com o apoio, proteção, cumplicidade, simpatia, a condescendência ou o simples silêncio de cidadãos tidos como respeitáveis, como igualmente ocorreu com os piratas.

\footnotetext{
${ }^{4}$ KENNEY, Dennis J.; FINCKENAUER, James. Apud: FERRO, Ana Luiza Almeida. Crime Organizado e Organizações Criminosas Mundiais. Curitiba: Juruá, 2009. P. 70.

${ }_{5}$ FERRO, Ana Luiza Almeida. Crime Organizado e Organizações Criminosas Mundiais. Curitiba: Juruá, 2009. P. 71.
} 
Um outro importante conceito que merece destaque é Máfia, pois não é qualquer grupo criminoso que se caracteriza como tal. É um fenômeno criminoso típico da Sicília ocidental, e suas origens estão relacionadas com a exploração do latifúndio. $O$ proprietário das terras subarrenda estas e passa a administração para um grande arrendatário, que coordena as ações de pequenos arrendatários, camponeses e trabalhadores braçais. Mesmo não possuindo leis escritas, há um código que rege as relações, e para assegurar o cumprimento de tais leis, os chefes contratavam milícias privadas (que em alguns casos eram compostas até mesmo por delinquentes). ${ }^{6}$

Este fato marca o nascimento da Máfia, característica da Itália, como: "forma de monopólio da violência que substitui os poderes do Estado e se encarrega de manter a 'ordem' além da lei.(...) A especulação e exploração parasitária como único meio para enriquecer, e a violência contra os mais fracos como forma para se impor na vida"7.

O crime organizado como é conhecido sofreu diversas mudanças desde os primórdios da sua existência, principalmente na era pós-capitalista. Em nível mundial, uma nova fase se deu com o fim da Guerra Fria, em 1989, quando essas organizações souberam aproveitar a situação da queda da União Soviética e o desmoronamento das antigas fronteiras, passando a atuar em redes e em caráter internacional, tirando proveito das oportunidades de negócios lícitos e ilícitos.

No mundo contemporâneo em que se vive hoje, segundo Guilherme Werner, é importante analisar o crime organizado através de algumas perspectivas: a primeira é política, onde o crime organizado transnacional é a resultante de uma estrutura estatal fraca, com baixo grau de representatividade e articulação das instituições públicas. A segunda é a econômica, devido à demanda do mercado por bens e serviços ilícitos. $E$ uma terceira seria a social, através da identificação da existência dos

\footnotetext{
${ }^{6}$ BOBBIO, Norberto; MATTEUCCI, Nicola e PASQUINO, Gianfranco. Dicionário de Política. Trad. Carmen C. Varriale [et al.]. $5^{a}$ edição. Brasília: Editora Universidade de Brasília; São Paulo: Imprensa Oficial do Estado, 2000. p. 726.

${ }^{7}$ Ibidem, p. 726.
} 
elementos sociais, culturais e étnicos, onde em alguns casos, a ausência do Estado é suprida por um chefe ou traficante poderoso. ${ }^{8}$

A atividade criminosa exerce considerável influência em várias economias nacionais. Em certos casos, o volume do capital supera toda a economia do país. Em outros, como na Colômbia, Peru, Bolívia ou Nigéria, tem tamanha representatividade que condiciona os processos macroeconômicos, exercendo papel decisivo em regiões ou setores específicos. $^{9}$

Durante um período, a estratégia central das organizações criminosas era se infiltrar nas instituições do Estado, nacionais e locais, do seu país de origem, para manter mais facilmente o bom andamento de suas atividades. A máfia siciliana, a Yakuza, as tríades de Hong Kong e Taiwan, os cartéis colombianos, todos visam possuir e manter elos fortes com burocratas e políticos, e esse elemento tão importante, só é possível sobreviver através da corrupção e intimidação de funcionários do Estado.

\section{1 - Tipologia de atividades criminosas transnacionais}

\subsection{1 - Tráfico de drogas}

É o tipo de crime mais lucrativo do mundo, maior inclusive que a renda interna de muitos países, opera algo em torno de US $\$ 320$ bilhões anuais. Para analisar esse típico de tráfico, é importante levar-se em conta as dimensões políticas e sociológicas da região, pois sua estrutura e seu modus operandi, respondem tanto às demandas de mercado transnacional como também fatores de ordem doméstica e mesmo individual. Este tipo de crime será analisado com mais detalhes no próximo capítulo.

\subsection{2 - Tráfico de armas}

\footnotetext{
${ }^{8}$ WERNER, Guilherme Cunha. O Crime OrganizadoTransnacional e as Redes Criminosas: Presença e Influência nas Relações Internacionais Contemporâneas. São Paulo: Universidade de São Paulo, 2009. p.16.

${ }^{9}$ CASTELLS, Manuel. Fim do Milênio. Trad. Klauss Brandini Gerhardt e Roneide Venâncio Majer. São Paulo: Paz e Terra, 1999. p. 239.
} 
O tráfico internacional de armas é a segunda atividade mais rentável no mundo do crime. Durante a Guerra Fria, o comércio e a transferência de armas se proliferaram, pois existiam restrições apenas às transferências entre os blocos soviético e americano, no entanto, entre países aliados ou organizações não estatais aliadas, essa movimentação foi muito intensa. Diante desse cenário, com o fim da Guerra Fria, a fase de transição para um mundo capitalista foi caótica e nisso se aproveitaram às redes criminosas, apossaram-se de grande quantidade de armamentos militares e nucleares, para vendê-los a quem pagasse mais.

O ponto chave desse negócio é a identidade do usuário final, pois pode acontecer as chamadas transferências autorizadas, de acordo com o Instituto das Nações Unidas para Pesquisa sobre Desarmamento (UNIDIR), onde envolve pelo menos um governo e estão de acordo com leis e tratados. Já o processo ilícito entre governos pode ocorrer quando determinados Estados estão impedidos de terem acesso a certos tipos de armas, por acordos internacionais ou embargos.

Nos termos do relatório da ONU: "independentemente do usuário final, o mercado negro de armas apresenta três características básicas: constitui uma atividade velada; grande parte do custo tem relação direta com a natureza escusa da transação; e o dinheiro correspondente ao fluxo de receita gerado é lavado". ${ }^{10}$

O tráfico se beneficia das falhas no monitoramento do que é produzido e armazenado, com destaque para os países em desenvolvimento, que às vezes não possuem recursos adequados ou através da corrupção, onde há pessoas corrompidas em etapas importantes do processo como alfândega, órgãos governamentais responsáveis (obtendo documentações legais e desviando o destino da mercadoria) e dentro das forças armadas (neste caso, abre caminho para armamentos a baixo custo) $)^{11}$.

\footnotetext{
${ }^{10}$ CSE-ONU (1994:18). Apud: CASTELLS, Manuel. Fim do Milênio. Trad. Klauss Brandini Gerhardt e Roneide Venâncio Majer. São Paulo: Paz e Terra, 1999. p. 212.

${ }^{11}$ PAES, Diego Cristóvão Alves de Souza. Tráfico llegal de Armas.
} 
O maior traficante de armas dos últimos tempos é um russo chamado Viktor Bout ${ }^{12}$, que foi preso em Bancoc, na Tailândia, no dia 06 de Março de 2008. Bout é muito citado em relatórios da ONU como grande fornecedor de armamentos de regiões em conflito, como Afeganistão, Angola, Libéria, Congo, Paquistão, Filipinas, Ruanda, Serra Leoa, Sudão e Colômbia. O traficante estava na lista dos mais procurados da Organização Policial Criminal Internacional (a INTERPOL); declara-se como dono de uma empresa de transportes, negócio legítimo, tendo, inclusive, prestado serviços para ONU, Estados Unidos e Reino Unido. ${ }^{13}$

$\mathrm{Na}$ década de 1990, Bout estabeleceu diversas relações comerciais: vendeu armas para ambos os lados da guerra no Afeganistão; forneceu armas no conflito em Angola, tanto para o governo, quanto para as forças rebeldes da União Nacional para a Independência Total da Angola (UNITA, partido político angolano que lutou na guerra de independência e na guerra civil). O grande diferencial desse traficante era sua rede de contatos, que 0 permitia atuar facilmente no âmbito global, pois tinha contatos no exército da antiga União Soviética (e com isso conseguia armamentos a baixos custos) e conseguiu sua própria frota de transportes. ${ }^{14}$

\subsection{3 - Tráfico de pessoas}

A Convenção das Nações Unidas Contra o Crime Organizado Transnacional, conhecida como Convenção de Palermo, define tráfico de pessoas como:

"o recrutamento, o transporte, a transferência, o alojamento ou o acolhimento de pessoas, recorrendo à ameaça ou uso da força ou outras formas de coação, ao rapto, à fraude, ao

Disponível em:

$<$ http://www.pucminas.br/imagedb/conjuntura/CNO ARQ NOTIC20080409090002.pdf.> Acesso em: 25/02/2010.

${ }^{12}$ Viktor Bout era integrante da KGB, central de inteligência da Rússia, que viu sua carreira acabar com o colapso da União Soviética. Os feitos de Bout geraram uma superpodução cinematográfica, intitulada Lord Of War (O Senhor das Armas, em português), em 2005.

${ }_{13}$ PAES, Diego Cristóvão Alves de Souza. Tráfico llegal de Armas. Disponível em: $<$ http://www.pucminas.br/imagedb/conjuntura/CNO ARQ NOTIC20080409090002.pdf.> Acesso em: 25/02/2010.

14 PAES, Diego Cristóvão Alves de Souza. Tráfico llegal de Armas. Disponível em: $<$ http://www.pucminas.br/imagedb/conjuntura/CNO ARQ NOTIC20080409090002.pdf.> Acesso em: 25/02/2010. 
engano, ao abuso de autoridade ou à situação de vulnerabilidade ou à entrega ou aceitação de pagamentos ou benefícios para obter consentimento de uma pessoa que tenha autoridade sobre outra para fins de exploração. A exploração incluirá, no mínimo, a exploração da prostituição de outrem ou outras formas de exploração sexual, o trabalho ou serviços forçados, escravatura ou práticas similares à escravatura, a servidão ou a remoção de órgãos".

Considerado o terceiro tipo crime mais lucrativo, perdendo apenas para o tráfico de drogas e armas, o tráfico de pessoas acontece em diversos países do mundo, dentro de um mesmo país, até entre diferentes continentes. Segundo um relatório da OIT (Organização Internacional do Trabalho), publicado em 2005, estimou que cerca de 2,4 milhões de pessoas no mundo foram traficadas, para serem submetidas a meios de exploração, inclusive explorações sexuais ${ }^{15}$. De acordo com estimativas do escritório das Nações Unidas contra Drogas e Crime (UNODOC), o lucro anual com cada ser humano, pode chegar a 30 mil dólares, é uma atividade de baixos riscos e altos lucros.

As principais vítimas são mulheres e crianças, normalmente de classes menos favorecidas, que estão desesperadas por dinheiro, com promessas de empregos, bons salários ou até mesmo um casamento, isto é, uma vida muito melhor e 'encantada' no exterior. Os principais destinos são: Espanha, Bélgica, Alemanha, Holanda, Itália, Reino Unido, Portugal, Suíça, Suécia, Noruega e Dinamarca. A maioria das mulheres vem de regiões do Leste Europeu, como Rússia, Ucrânia, Albânia, Kosovo, República Tcheca e Polônia; também do sudeste asiático, Filipinas e Tailândia; da África, Gana, Nigéria e Marrocos; e por fim de países da América Latina como, Brasil, Colômbia, Equador e República Dominicana. ${ }^{16}$

O combate a este tipo de crime não é tarefa fácil, visto que, não é cometido somente por grandes redes criminosas, mas o mais comum são associações feitas entre os criminosos, já que alguns se especializam em áreas específicas, como recrutamento ou transporte e administração de

\footnotetext{
${ }^{15}$ DIAS, Cláudia Sérvulo da Cunha (coord). Tráfico de Pessoas para Fins de Exploração Sexual. Brasília: OIT, 2005. p.12.

${ }^{16}$ Ibidem, p.13.
} 
prostíbulos. E para que a operação seja bem sucedida, é preciso ter controle sobre a vítima, que ocorre de diversas formas, entre elas: confiscam seus documentos, por meio da intimidação, ameaça, estupro e o medo; em diversos casos ameaçam familiares e amigos da vítima, para que esta saiba que seus entes queridos poderão sofrer caso ela queira fugir.

\subsection{4 - Lavagem de dinheiro}

O termo "lavagem de dinheiro", teve sua origem nos Estados Unidos (money laundering), na década de 1920, onde uma rede de lavanderias fazia o trabalho de colocar no mercado o dinheiro oriundo de atividades ilícitas, conferindo-Ihe a aparência de lícito. Essa expressão refere-se à "intenção de ocultar a origem ilegal de recursos para que, num momento posterior, eles possam ser reintroduzidos na economia revestidos de legitimidade". ${ }^{17}$

Esse processo envolve três etapas: a colocação, ocultação e integração. A colocação (em inglês placemente), é a primeira etapa, onde o criminoso tenta inserir o "dinheiro sujo" no sistema econômico, diluindo materialmente os valores, para não chamar a atenção das autoridades financeiras, fazendo vários depósitos em contas diversas, comprando instrumentos negociáveis ou outros bens. Nesta etapa, há uma preferência por países com regras não tão rígidas, pois quanto menor a possibilidade de identificação da procedência do dinheiro, melhor $^{18}$.

A segunda etapa é a ocultação (em inglês layering), após a inserção no mercado financeiro, os ativos ilícitos devem ser desvinculados de sua origem. Neste processo realizam-se diversas operações complexas, tanto em nível nacional quanto internacional, interrompendo uma sequência de evidências, caso a origem do dinheiro venha a ser investigada. Muitos criminosos dão preferências a países que adotam leis de sigilo bancário. ${ }^{19}$

\footnotetext{
${ }^{17}$ MINK, Gisele Fernandes Cardoso. Lavagem de Dinheiro. Rio de Janeiro: Universidade Federal do Rio de Janeiro, 2005. p. 8.

${ }^{18}$ Ibidem, p. 9.

${ }^{19}$ Ibidem, p. 10.
} 
A última etapa é a integração (do inglês inegration), onde ocorre o retorno do dinheiro, já "limpo", ao sistema financeiro, para investimento em ativos (lícitos ou não) ou utilização na economia legal. ${ }^{20}$

O crime de lavagem de dinheiro trata-se de uma ameaça internacional e as medidas para controlar o problema tornaram-se foco de um intenso esforço internacional. Especialistas estimam que cerca de US\$ 500 bilhões em "dinheiro sujo" - cerca de $2 \%$ do PIB mundial - transitam anualmente na economia. É necessária uma vigilância constante dos Estados perante suas instituições financeiras, pois se não controlado, esse fato pode prejudicar a confiança pública em sua integridade. ${ }^{21}$

O Brasil hoje é referência mundial em iniciativas concretas visando desarticular as atividades das organizações criminosas, inclusive ampliando os mecanismos de prevenção e combate à lavagem de dinheiro. A fórmula é simples: estímulo à cooperação jurídica com outros países e articulação interna. Internacionalmente ratificou a Convenção de Viena de 1988, da $\mathrm{ONU}$, visando o combate ao tráfico de entorpecentes e à cooperação jurídica entre as partes. Internamente, criou importantes órgãos que servem como instrumento para tratar a corrupção, fluxo de dinheiro resultado de fraudes e crimes, como tráfico de drogas. São eles: Departamento de Combate a llícitos Cambiais e Financeiros no Banco Central e o Conselho de Controle de Atividades Financeiras (COAF), unidade de inteligência financeira. ${ }^{22}$

Convém ilustrar um caso clássico de lavagem de dinheiro:

"O caso de Franklin Jurado (EUA, 1990-1996), ecomonista colombiano, formado em Harvard, Jurado coordenou a lavagem de cerca de US\$36 milhões em lucros obtidos por José Santacruz-Londono com comércio ilegal de drogas.

O depósito inicial (algo usualmente feito em países onde não há regulamentação, países com instituições governamentais frágeis) - estágio mais arriscado, pois o dinheiro está próximo de suas origens - foi feito no Panamá.

\footnotetext{
${ }^{20}$ Ibidem, p. 10.

${ }^{21}$ Cartilha - Lavagem de Dinheiro: Um problema mundial. Disponível em: $<$ https://www.coaf.fazenda.gov.br/conteudo/publicacoes/cartilha-lavagem-de-dinheiro-umproblema-mundial/>. Acesso em 10/03/2010.

${ }^{22}$ TUMA JÚNIOR, Romeu. Brasil: modelo na prevenção e combate à lavagem de dinheiro. Disponível em:

$<$ http://portal.mj.gov.br/main.asp?Team=\%7B9668E5B2\%2D1F9C\%2D4106\%2DB0E8\%2D F32CB3A0B80E\%7D >. Acesso em 10/03/2010.
} 
Durante um período de três anos, Jurado transferiu dólares de bancos panamenhos para mais de 100 contas diferentes em 68 bancos de nove países, mantendo os saldos abaixo de US 10.000,00 para evitar investigações.

Os fundos foram novamente transferidos, dessa vez para contas na Europa, de maneira a obscurecer a nacionalidade dos correntistas originais, e, então, transferidos para empresas de fachada. Finalmente, os fundos voltaram à Colômbia por meio de investimentos feitos por companhias européias de negócios legítimos, como restaurantes, construtoras e laboratórios farmacêuticos, que não levantariam suspeitas.

O esquema foi interrompido com a falência de um banco em Mônaco, quando várias contas ligadas a Jurado foram expostas. Fortalecida por leis antilavagem, a polícia começou a investigar o caso e Jurado foi preso." 23

\subsection{5 - Contrabando de imigrantes ilegais}

A grande desigualdade econômica entre os países, uns tão miseráveis e outros tão desenvolvidos, levam milhões de pessoas à emigração. Os países mais desenvolvidos estão, cada vez mais, intensificando seus controles de fronteira, com critérios bastante rigorosos para conter esse fluxo migratório. Nessa circunstância entra as organizações criminosas, com uma grande oportunidade de explorar um imenso mercado.

Segundo relatório da CSE-ONU de 1994 estima que o volume do tráfico ilegal de imigrantes de países pobres para os mais ricos seja de aproximadamente um milhão de pessoas por ano, mas acredita-se que esse número seja bem maior. O lucro dessas organizações criminosas pode ser além do pagamento propriamente dito, efetuado pelo 'serviço', como também através de regime de trabalho escravo, durante muito tempo para poderem pagar os custos, e isso a juros muito altos. ${ }^{24}$

Nessas circunstâncias os imigrantes são expostos a fraudes, abusos, violência e morte. Além disso, devido ao seu grande volume, esse processo ajuda a desencadear uma reação de xenofobia, que, em alguns casos,

\footnotetext{
${ }^{23}$ Cartilha - Lavagem de Dinheiro: Um problema mundial. Disponível em: $<$ https://www.coaf.fazenda.gov.br/conteudo/publicacoes/cartilha-lavagem-de-dinheiro-umproblema-mundial/>. Acesso em 10/03/2010.

${ }^{24}$ CASTELLS, Manuel. Fim do Milênio. Trad. Klauss Brandini Gerhardt e Roneide Venâncio Majer. São Paulo: Paz e Terra, 1999. p. 214.
} 
manipulada por certos políticos, aumenta a intolerância e diminui o sentimento de solidariedade.

É apropriado apontar uma questão, a importante diferença entre tráfico e contrabando de imigrantes. O primeiro é algo mais grave, incluindo maior violência, ameaça, fraude e exploração; já o segundo é como um 'serviço' prestado para uma pessoa que queira entrar num determinado país de forma ilegal. De acordo com a ONU, o contrabando deve ser entendido como algo para "facilitar a entrada ilegal de uma pessoa num Estado do qual essa pessoa não é nacional ou residente permanente com o objetivo de obter, diretos ou indiretamente, um benefício financeiro ou outro benefício material”25. Em outros termos, o tráfico pode ser considerado um crime contra a pessoa, e o contrabando, um crime contra o Estado.

\subsection{6 - Pirataria marítima}

A pirataria foi um fenômeno que surgiu no final do século XVIII, e que ressurgiu em pleno século XXI, cujo objetivo é atacar navios de carga, e com isso roubar sua carga e sequestrar tripulantes, fazendo pedido de resgate ao país de origem da vítima. Prejudicando bastante o comércio internacional, pois quem insiste em navegar nessas águas, cujo risco de pirataria é alto, acabam sendo obrigados a investirem em seguros altos; ou quem prefere buscar outras rotas, acabam pagando mais frete, ou seja, o custo é repassado à carga, mesmo quem está longe acaba sendo prejudicado. ${ }^{26}$

Nos dias de hoje, um caso de pirataria que merece destaque é o que ocorre numa região conhecida como Chifre da África, com foco na Somália. Um país caótico, com a população passando fome e a falta de um Estado

\footnotetext{
25 Trata-se do protocolo à Convenção das Nações Unidas contra a Criminalidade Organizada Transnacional, o Protocolo Adicional contra o Tráfico llícito de Migrantes por via Terrestre, Marítima e Aérea.

${ }^{26}$ A Somália por razões políticas é hoje um dos países com a maior participação mundial na pirataria de alto mar, desenvolvendo suas atividades no chifre da África, nas rotas comerciais do oceano Índico, gerando tensão internacional, e impondo ao Conselho de Segurança das Nações Unidas adoção de medidas destinadas a condenar os atos de pirataria e roubo de navios. (UN/SC/9344).
} 
atuante, a pirataria foi um meio encontrado de conseguir dinheiro 'fácil', o que se estima que, atualmente, seja em torno de 2.000 pessoas. $^{27}$

Há três grupos que fazem parte da quadrilha da pirataria: aqueles que ficam responsáveis por rastrearem mensagens, para localizar alvos e ficar alerta sobre possíveis navios militares; outros que executam a operação, conduzindo rebocadores e lanchas até os alvos; e por último, o grupo que forma a força de ataque aos navios, neste grupo há bastantes veteranos da guerra civil da Somália. Os piratas somalis simulam um pedido de socorro para atrair o navio-alvo para as águas do país africano, ao diminuírem a velocidade, é lançado ao navio granadas para intimidação, e após isso, os criminosos escalam o navio através de cordas e rendem a tripulação. $A$ renda vem por meio de roubo da carga e, o mais comum, pedido de resgate à companhia do navio ou país de origem dos tripulantes. ${ }^{28}$

O dinheiro arrecadado com a pirataria, na Somália, faz esses piratas dormirem miseráveis e acordarem milionários. A população os descrevem como homens cheios de dinheiro, donos de mansões, dão as melhores festas, que dirigem carros luxuosos e muitos são donos de comércios locais, como hotéis. E devido à grande miséria do país, fica difícil resistir a uma forma de ganhar dinheiro tão fácil.

\section{TRÁFICO DE DROGAS}

\footnotetext{
${ }^{27}$ Os Piratas da Somália. Disponível em: <http://veja.abril.com.br/educacao/piratassomalia/piratas-somalia.html>. Acesso em 05/03/2010.

${ }^{28}$ Os Piratas da Somália Disponível em: <http://veja.abril.com.br/educacao/piratassomalia/piratas-somalia.html>. Acesso em 05/03/2010.
} 
Neste segundo capítulo será analisado com mais profundidade o tráfico de drogas, como também exemplos de países, como Itália, Colômbia, e Brasil, com situação mais delicada sobre o tema e estatísticas a respeito.

No crime global existem diversas organizações enraizadas nacional, regional e culturalmente, uma grande parte possui uma longa história, com suas ideologias, códigos de conduta e mecanismos próprios para a entrada de novos membros, pois uma vez que entram no sistema, irá fazer parte dele pelo resto da vida.

Desde a década de 1970, houve um grande aumento na indústria do tráfico de drogas, influenciando fortemente a economia e a política. $\mathrm{Na}$ América Latina, concentra-se a produção, processamento e exportação de coca e cocaína ${ }^{29}$ (ver Anexo 1). No entanto, a partir dos anos 90 a heroína ${ }^{30}$ tornou-se uma "mercadoria" também importante, juntamente com a maconha. Diante dessa perspectiva, o narcotráfico para Procópio Filho e Costa Vaz:

"As estruturas do narcotráfico e sua operação respondem tanto a estímulos de mercado, em sua dimensão transnacional e global, como a fatores e circunstâncias de ordem doméstica e mesmo local que definem o modo de inserção de um país no contexto do narcotráfico internacional $e$ as condições específicas de seu funcionamento". 31

\footnotetext{
${ }^{29}$ Há uma grande diferença entre coca e cocaína. A folha da coca é matéria-prima utilizada para a fabricação da cocaína, que é necessário seu preparo em laboratório. A cocaína para o consumo é obtida através do tratamento de folhas de coca secas. O processo é feito em duas etapas: produção de pasta-base e, a partir dessa pasta, obtenção da cocaína. A cocaina é o principal alcalóide do arbusto Erythroxylon. Existem cerca de 200 espécies, mas apenas 17 delas são utilizadas para extração de cocaína. É cultivada em clima tropical". ARBEX JÚNIOR, José. Narcotráfico - Um jogo de poder nas Américas. São Paulo: Modernas, 1993. p. 21. Disponível em:

$<$ http://psicoativas.ufcspa.edu.br/vivavoz/revisoes/cocaina.pdf >. Acesso: 12/03/2010.

${ }_{30}$ "A heroína é uma droga derivada da papoula e como outras drogas originárias dessa planta, a heroína atua sobre receptores cerebrais específicos, provocando um funcionamento mais brando do sistema nervoso e respiratório. Seus efeitos duram aproximadamente cinco horas, proporcionando sensações de bem-estar, euforia e prazer; elevação da auto-estima e diminuição do desânimo, dor e ansiedade." Foi proibida na década de 1920 após descobrir-se seu grande potencial de causar dependência química e psíquica rapidamente. Disponível em < http://www.brasilescola.com/drogas/heroina.htm > Acesso em: 12/03/2010.

${ }^{31}$ PROCÓPIO FILHO, Argemiro; VAZ, Alcides Costa. O Brasil no contexto do narcotráfico internacional. In: Revista Brasileira de Política Internacional. Brasília, no1, 1997, p.87.
} 
Segundo Manuel Castells, a indústria do narcotráfico possui cinco importantes características. A primeira delas é que está direcionada à demanda e à exportação, tendo como grande mercado os Estados Unidos, apesar do grande crescimento de abastecimento para Europa Ocidental e partes mais ricas da Ásia.

A segunda é que "a indústria é totalmente internacionalizada, com uma divisão bastante rigorosa da mão-de-obra entre os diferentes locais do processo produtivo". Ou seja, sua produção tem sido feita de forma bastante segura. Um bom exemplo é o Peru, que sozinho corresponde a $55 \%$ da produção das folhas de coca, em seguida vem a Bolívia, com cerca de $35 \%$, e o restante vem do Equador, Colômbia, Venezuela, Brasil e México. Para transformar as folhas de coca em pasta e posteriormente em base de coca, de modo geral são feitos a certa distância dos campos de cultivo para dificultar a sua descoberta.

O método de transporte é, inevitavelmente, feito através de suborno de agentes da alfândega, de um ou mais países. Para mercados mais distantes, como Europa e Ásia, o processo é feito, principalmente, através de navios cargueiros, e quando estão próximos da costa, são descarregados para pequenas embarcações.

A terceira característica é "o componente essencial de toda a indústria da droga é o sistema de lavagem de dinheiro". Esse processo é, em grande parte, controlado por cartéis mexicanos e colombianos, que contam com apoio de funcionários corruptos de instituições bancárias na Colômbia, Venezuela, Panamá e Flórida; outras instituições financeiras que têm papel importante nesse processo encontram-se nos chamados 'paraísos fiscais' como llhas Cayman, Turcos y Caicos, Aruba e nas Bahamas.

Uma quarta característica é "o cumprimento de todo o conjunto de transações é assegurado por meio do uso de violência em um nível extraordinário". Toda importante organização criminosa possui uma rede de assassinos, em muitos casos, profissionais. Esses assassinos, além de garantir o bom funcionamento das operações, eles também atuam fortemente na concorrência e proteção, nas situações em que as 
organizações criminosas lutam entre si pelo controle de mercado ou na partilha dos lucros.

A última característica diz "a indústria da droga precisa da corrupção e da penetração em seu meio institucional para poder funcionar, em todas as etapas do sistema". Os chefões do tráfico precisam corromper e/ou intimidar pessoas essenciais para o esquema funcionar, tais como polícia, alfândega, juízes, políticos, banqueiros, químicos, jornalistas, transportadores e empresários. Esse controle feito pelos traficantes é mais bem sucedido na ausência de um poder estatal mais decisivo. ${ }^{32}$

\section{1 - Colômbia}

O tráfico de drogas voltado à exportação na Colômbia teve seu início nos anos 1970, na região da La Guajira, onde era feito o comércio da maconha ${ }^{33}$ produzida próximo a Santa Marta. A máfia norte-americana trabalhava em conjunto com redes criminosas colombianas para o envio da droga para os Estados Unidos. Devido ao seu grande volume e pouco valor agregado, à época, as grandes despesas com suborno de funcionários, tornavam-na pouco competitivas. A partir daí, mafiosos norte-americanos, através de seus contatos, apontaram para um produto que poderia ser mais lucrativo, para ser cultivado por esses produtores: a coca. ${ }^{34}$ Além do cultivo da coca, essas redes poderiam controlar o tráfico, ainda pouco explorado à época, realizado na Bolívia, Equador, Peru e Chile.

Medellín, capital de Antioquia, era o berço empreendedor colombiano. Nos anos 1970, sua indústria têxtil passava por uma grave crise devido à concorrência internacional imposta pelas fibras sintéticas. O mesmo ocorreu com Cali, capital de Valle del Cauca, onde a indústria açucareira sofreu

\footnotetext{
${ }^{32}$ CASTELLS, Manuel. Fim do Milênio. Trad. Klauss Brandini Gerhardt e Roneide Venâncio Majer. São Paulo: Paz e Terra, 1999. p. 230.

${ }^{33}$ A maconha são as flores e folhas secas da planta cannabis sativa. Também conhecida popularmente como: marijuana, fumo, bagulho, manga rosa, liamba, mulatinho. Outra preparação da Canabis é o haxixe. Seus efeitos normalmente são: os sentidos ficam mais aguçados, apesar do indivíduo ficar com menor equilíbrio e força muscular; relaxamento e sonolência, boca seca, aumento da vontade de comer doces, alucinações e delírios. Disponível em: <http://www.unifesp.br/dpsicobio/cebrid/quest drogas/maconha.htm>. Acesso em: 12/03/2010.

${ }^{34}$ Op. Cit., p.234.
} 
grande impacto pelas cotas de exportação impostas pelo comércio internacional. E uma terceira região que é importante citar é Boyaca, no centro do país, que também passou por uma crise na mineração e no contrabando de esmeraldas, atividade econômica dominante da região. Essas três regiões transformaram-se em grandes cartéis do tráfico de cocaína. ${ }^{35}$

Boyaca, sob administração de um líder violento, Rodriguez Gacha aliou-se ao grupo de Medellín, sob chefia de Pablo Escobar e a família Ochoa. Cali, chefiados pelos irmãos Rodriguez Orejuela, montou rede própria de tráfico, e constantemente entravam em conflito com o grupo de Medellín.

O grupo de Cali teve suas origens na classe média alta, e sendo assim, nunca desafiou as oligarquias colombianas, que tinha muito poder nos negócios, prestígio, riqueza, terras e influência política. ${ }^{36}$

O grupo de Medellín, diferentemente de Cali, suas origens são mais pobres, vivendo numa cultura onde somente a riqueza permite que se conquiste algum respeito. Os componentes desse grupo também tinham suas redes de influência na política, tanto que em 1982, Pablo Escobar foi eleito para o Congresso Colombiano, apesar de ter durado pouco tempo, devido à intervenção da Embaixada Americana.

O tratamento entre esses grupos e suas respectivas 'populações' eram bem diferentes. Pablo Escobar, chefiando o grupo de Medellín, financiou sistemas habitacionais e serviços sociais para o povo de baixa renda, desenvolveu infra-estrutura significativa para os habitantes da favela, coisa que o Estado não fazia. Escobar tentou até defender os direitos humanos, de seus jovens que sofriam com os abusos cometido pela polícia nacional. Um dos lados negativos do grupo para a população era o fato de fazerem uma espécie de limpeza social, onde matavam os "desechables"

\footnotetext{
${ }^{35}$ CASTELLS, Manuel. Fim do Milênio. Trad. Klauss Brandini Gerhardt e Roneide Venâncio Majer. São Paulo: Paz e Terra, 1999. p. 235.

${ }^{36}$ Ibidem, p. 236.
} 
(descartáveis), que eram os sem-teto, as prostitutas, crianças de rua, pedintes e homossexuais. $^{37}$

Os grupos de Cali e Medellín desejavam uma total inserção na comunidade colombiana. Em diversos momentos eles ofereceram, a vários presidentes, a pagarem em dinheiro a dívida externa do país (na casa dos bilhões de dólares) e reinvestir dinheiro na Colômbia, tornando-se legítimos empresários. Mas essa proposta foi totalmente contestada pelo governo americano, que queriam impedir que a Colômbia se transformasse no porto seguro dos traficantes.

Segundo Castells, "a permanência e o apego dos traficantes de drogas ao próprio país e suas regiões vão além de um cálculo meramente estratégico. Eles estão profundamente apegados a suas respectivas culturas, tradições e sociedades regionais". Os traficantes não apenas reinvestiam o dinheiro da droga na própria comunidade, como davam uma nova energia na economia local, reconstruíram a vida rural, deram apoio a folclore e fizeram times de futebol colombianos. Um traficante como Pablo Escobar, apesar da violência do grupo e da forma ilícita de ganhar dinheiro, tinha seus feitos para a comunidade e assim conquistou respeito e, para alguns, admiração, tanto que seu funeral ${ }^{38}$ foi uma homenagem prestada a ele pelo povo da cidade e, principalmente, pelos moradores mais pobres.

A queda dos cartéis de Cali e Medellín, foi a partir da década de 1990, onde iniciaram ataques uns contra os outros, com altos índices de violência. O primeiro a se desfalecer foi o Cartel de Medellín, com grandes rivais em várias cidades colombianas (aliados dos traficantes de Cali), onde até mesmo se formou um grupo chamado PEPES, pessoas contra Pablo Escobar, e com isso atacaram casas, empresas e o que mais pudessem para capturar Escobar ou destruir seus negócios. Escobar teve seu fim em dezembro de 1993, morto a tiros.

Com o enfraquecimento do cartel de Medellín, o cartel de Cali estava prosperando nos negócios, onde empregavam técnicas de grupos

\footnotetext{
${ }^{37}$ Ibidem, p. 236.

${ }^{38}$ Pablo Escobar foi morto a tiros no telhado de uma das casas da cidade de Medellín, em dezembro de 1993
} 
terroristas, separando os 'funcionários' em células, e cada um sabendo pouco a respeito do outro; contrataram investigadores para seguirem os passos do DEA (Drug Enforcement Administration) e as ações do governo americano, a cerca das drogas e investiam pesado em proteção política. Mas, também em meados da década de 1990, as ações da polícia colombiana, em conjunto com órgãos dos Estados Unidos, conseguiram prender os principais chefes do Cartel de Cali, o que acabou resultando na sua destruição. Mesmo assim, surgiram outros grupos, com características um pouco diferentes, para suprir esse 'vazio' deixados pelos dois poderosos cartéis. $^{39}$

Desde a época do governo Reagan (1980-1988), os Estados Unidos têm a postura de que as drogas são um problema de segurança nacional, e que o combate deveria ser feito diretamente na 'fonte', isto é, nos países produtores, e nisso se enquadrava Bolívia, Peru, Colômbia e, posteriormente, o México. ${ }^{40}$

Em 1995, o governo colombiano fez uma parceria com os EUA (na época quem comandou era o então presidente dos EUA, Bill Clinton), onde os norte-americanos iriam introduzir tropas militares (uma parte seria do exército norte-americano e outra parte pessoas contratadas) e dinheiro na Colômbia. Ficou conhecido como Plano Colômbia, este plano teve como um dos objetivos, diminuir o envio e consumo de cocaína nos EUA (que segundo tais líderes, grande quantidade da droga viria da Colômbia), como também o plantio da coca (da qual deriva a cocaína). Mais de $80 \%$ do incentivo econômico dos EUA na Colômbia foram para a aquisição de armas. Apesar da intervenção dos EUA, o plano fracassou, pois não conseguiram diminuir o consumo de coca nem o plantio. ${ }^{41}$

\footnotetext{
${ }^{39}$ The Colombian Cartels. Disponível em: $<$ http://www.pbs.org/wgbh/pages/frontline/shows/drugs/business/inside/colombian.html> Acesso em 20/03/2010.

${ }^{40}$ VILLA, Rafael Duarte, OSTOS, Maria Del Pilar. As relações Colômbia, países vizinhos e Estados Unidos: visões em torno da agenda de segurança. In: Revista Brasileira de Política Internacional. Brasília, ano 48, n.2, jul-dez 2005. p.87.

${ }^{41}$ BRITTAIN, James J. The Continuity of FARC-EP Resistance in Colombia. Disponível em:

$<$ http://www.counterpunch.org/brittain08012008.html > Acesso em: 15/03/2010.
} 
Com a subida de George W. Bush ao poder nos EUA, que se assumiu como a pessoa que irá "combater o terror" após os atentados de 11 de Setembro, fez-se outra tentativa de se acabar com o conflito na Colômbia (o problema com o grupo guerrilheiro FARC - Forças Revolucionárias da Colômbia) e o problema das drogas, desta vez chamado de Plano Patriota, semelhante ao anterior. Seria uma 'guerra' contra as drogas e uma tentativa, de acabar com as FARC que foi por Bush chamados de terroristas. Apesar de Bush tentar chamar a atenção da mídia para divulgação de que o Plano Patriota estava funcionando, não foi bem assim que aconteceu. Pelo contrário, as FARC estão cada vez mais aumentando seu arsenal de armas e combatentes. Como também o cultivo da coca que permanece como tal. Ou seja, o Plano não conseguiu o que foi almejado. ${ }^{42}$

Mesmo com toda repressão ao tráfico, a Colômbia continua sendo um importante centro de refino e técnicas avançadas no processamento da coca.

\section{2 - ITÁLIA}

É na Itália que surge o mais representativo tipo de organização criminosa, pela sua longevidade e importância no cenário da criminalidade: a Máfia siciliana.

Primeiramente é importante salientar que, o termo máfia é comumente utilizado pelos meios de comunicação, podendo significar grupos distintos, com características bem diferentes. Segundo Salvatore Lupo:

"a Máfia foi vista como espelho da sociedade tradicional, com atenção aos fatores políticos, econômicos ou - com maior frequência - socioculturais; como empresa ou tipo de indústria criminosa; como organização secreta mais ou menos centralizada; como ordenamento jurídico paralelo ao do Estado, ou como anti-Estado." ${ }^{43}$

${ }^{42}$ FONTES, Yuri Martins. FARC: 40 anos de História. Disponível em: <http://www.consciencia.net/2004/mes/07/farc-40anos.html> Acesso em: 15/03/2010. ${ }^{43}$ LUPO, Salvatore. História da Máfia: das origens aos nossos dias. Trad. Álvaro Lorencini. São Paulo: Editora UNESP, 2002. p. 21. 
De acordo com Ana Luiza Ferro, a máfia possui quatro fases em sua evolução, importantes para melhor entendimento de alguns aspectos do crime organizado. A primeira é a fase de incubação, que corresponde ao período do século $\mathrm{XVI}$ até o século XIX, considerando-se mais uma fase de pré-Máfia, do que propriamente uma verdadeira e própria.

A segunda é de uma "Máfia agrária", como herdeira e dando continuidade a uma ordem econômico-social embasada no campo, forte até a década de 1950 do século passado, no qual o mafioso constitui um portador da economia agrária.

Outra fase é a "urbano-empresarial" típica dos anos 50 aos 60 do século XX, provocando o surgimento de uma espécie de mafioso empresário, com um papel secundário nos setores que alcançavam um certo desenvolvimento, principalmente no setor das construções.

A quarta e última fase correspondem ao que se inicia após os anos 70, como uma "Máfia financeira", significando que nos atos ilegais, em conexão com os tráficos internacionais, principalmente drogas e armas, proporcionava ganho de grandes massas de capital e solidez sem precedentes. ${ }^{44}$

José Louzeiro traça um perfil da estrutura e do estágio da máfia:

"No início do século do século XX, na Itália, a máfia já era uma associação de delinquentes, com influência no processo político e econômico da província de Palermo e adjacências. Possuía uma estrutura, uma linguagem, era o instrumento de forças econômicas bem distintas." ${ }^{45}$

As organizações da Máfia italiana, mais relevantes são: Máfia siciliana, Camorra, 'Ndrangheta, Sacra Corona Unita e La Cosa Nostra.

\subsection{1 - Máfia Siciliana}

A Máfia siciliana (com base na Sicília) foi formada em meados de 1800 para unificar os camponeses sicilianos contra seus inimigos. A máfia

\footnotetext{
${ }^{44}$ FERRO, Ana Luiza Almeida. Crime Organizado e Organizações Criminosas mundiais. Curitiba: Editora Juruá, 2009. p. 78.

${ }^{45}$ LOUZEIRO, José. O Estado do Maranhão. São Luís, 14 set 2003. Caderno Especial, p.6. Apud: Ibidem, p. 77.
} 
siciliana saiu de um grupo de homens honrados e de trabalhadores honestos para um grupo criminoso organizado na década de 1920. Na década de 1950 se infiltrou na construção massiva, e aproveitando a oportunidade, passou a controlar muitos contratos de construção, e com isso ganhou muito dinheiro, e após disso, passou a ter forte atuação no mercado do crime organizado. Segundos especialistas, é a segunda maior organização na Itália. ${ }^{46}$

Esse grupo é especialista em tráfico de heroína, corrupção política e tráfico de armas militares. Também é conhecido por iniciar incêndios criminosos, fraudes, falsificação e outros crimes de extorsão. Segundo o FBI (Federal Bureau of Investigation, escritório federal de investigação dos Estados Unidos) a Máfia siciliana é o grupo italiano mais poderoso e ativo nos Estados Unidos e estima-se que exista 2.500 filiais em território americano. ${ }^{47}$

A Máfia siciliana é muito conhecida por seus ataques, com grande teor de violência, contra funcionários públicos italianos, responsáveis pela aplicação da lei. Existe até mesmo uma distinção entre um cidadão comum que é morto e um funcionário do governo, cujo nome é conhecido como "excelente cadáver", e seus alvos, nesse quesito, são: prefeitos, juízes, comissários de polícia, coronéis, generais de polícia e membros do Parlamento. Para exemplificar, vale lembrar do que aconteceu em 23 de maio de 1992, onde a máfia siciliana planejou e matou o magistrado italiano Giovanni Falcone, sua esposa e três guarda-costas da polícia, mortos por uma bomba, que fez um buraco de 30 metros de diâmetro. $O$ fato ficou conhecido como Massacre de Capaci. ${ }^{48}$

\subsection{2 - Camorra}

\footnotetext{
${ }^{46}$ Italian Organized Crime. Disponível em:< http://www.fbi.gov/hq/cid/orgcrime/lcnindex.htm> Acesso em: 20/03/2010.

${ }^{47}$ Italian Organized Crime. Disponível em:< http://www.fbi.gov/hq/cid/orgcrime/lcnindex.htm> Acesso em: 20/03/2010.

${ }^{48}$ Italian Organized Crime Disponível em:< http://www.fbi.gov/hq/cid/orgcrime/lcnindex.htm> Acesso em: 20/03/2010.
} 
A Camorra, ou Máfia Napolitana (com sede em Nápoles), apareceu pela primeira vez em meados de 1800, em Nápoles, como uns bandos de presos, que após serem soltos formaram pequenos clãs, cujo equilíbrio estava sujeito a contínuos ajustes, mas com poder em ascensão. Segundo o FBI, a Camorra tem mais de 100 clãs e aproximadamente 7.000 membros, sendo o maior grupo do crime organizado italiano. ${ }^{49}$

Na década de 1970 a Máfia Siciliana propôs a Máfia Napolitana a trocar suas rotas de contrabando de cigarro por contrabando de drogas, contando com a assistência dos criminosos sicilianos. Mas essa proposta não agradou a todos os líderes da Camorra, o que acabou gerando um conflito entre eles e a morte de 400 pessoas, e os que se opunham perderam.

Em 1980 houve um terremoto que devastou a região da Campania, e a Máfia aproveitou a oportunidade e se infiltrou na rescontrução da região, e fez fortuna com isso. A Camorra agora é especializada em contrabando de cigarros e recebe pagamento de outros grupos criminosos que também fazem contrabando de cigarro por toda Itália. Esta organização também está envolvida em lavagem de dinheiro, extorsão, tráfico, roubo, chantagem, sequestro, corrupção política e falsificação. ${ }^{50}$

\subsection{3 - 'Ndrangheta}

A Máfia 'Ndrangheta ou Máfia calabresa tem sua origem na região da Calábria. A palavra 'Ndrangheta vem do grego e significa coragem e lealdade. A máfia calabresa teve sua formação na década de 1860 , quando um grupo de sicilianos foram banidos da ilha pelo governo italiano, assim, se estabeleceram na Calábria e formaram pequenos grupos criminosos. A Calábria representa a região mais pobre da Itália, e uma das mais pobres da Europa, mostrando altos níveis de desemprego, principalmente entre os mais jovens. "A Camorra napolitana e a Ndrangheta calabresa, amiúde

\footnotetext{
${ }^{49}$ Italian Organized Crime Disponível em:< http://www.fbi.gov/hq/cid/orgcrime/lcnindex.htm> Acesso em: 20/03/2010.

${ }^{50}$ Italian Organized Crime Disponível em:< http://www.fbi.gov/hq/cid/orgcrime/lcnindex.htm> Acesso em: 20/03/2010.
} 
chamadas também elas de máfia, não possuem a estrutura unitária, hierarquizada e de compartimentos estanques da Cosa Nostra. Ambas têm uma organização por assim dizer horizontal." 51

De acordo com estimativas do FBI, existem cerca de 160 células 'Ndrangheta, com cerca de 6.000 membros. São especializados em sequestro e corrupção política; estão envolvidos também no tráfico de drogas, assassinatos, atentados, falsificação, roubos, extorsão de trabalho, agiotagem e tráfico de imigrantes. As células estão ligadas por grupos familiares baseadas em relações de sangue e casamentos. ${ }^{52}$

\subsection{4 - Sacra Corona}

A organização Sacra Corona Unita ou Coroa Sagrada Unida, sediada em Brindisi, no sudeste de Puglia, assim como outros grupos, começou como um grupo de prisioneiros. Ao serem soltos, seus integrantes de instalaram na região de Puglia e continuaram a crescer e formar vínculos com outros grupos da Máfia. Estimativas do FBI mostram que esta organização está constituída por cerca de 50 clãs, com aproximadamente 2.000 membros. Sua especialização é contrabando de cigarros, drogas, armas e pessoas. Também possui relação com crimes de lavagem de dinheiro, extorsão e corrupção política. A organização recebe dinheiro de outros grupos criminosos como permissão de desembarque na costa sudeste da Itália, um ponto importante para o contrabando do que está indo ou vindo de países como Croácia, Iugoslávia e Albânia. ${ }^{53}$

\subsection{5 - La Cosa Nostra}

La Cosa Nostra, tem suas raízes no crime organizado italiano, apesar de ter forte atuação além das fronteiras da Itália, tem sido uma organização independente por muitos anos. Hoje, La Cosa Nostra colabora com várias

\footnotetext{
${ }^{51}$ FERRO, Ana Luiza Almeida. Crime Organizado e Organizações Criminosas mundiais. Curitiba: Editora Juruá, 2009. p. 81.

52 Italian Organized Crime Disponível em:< http://www.fbi.gov/hq/cid/orgcrime/lcnindex.htm> Acesso em: 20/03/2010.

${ }_{53}$ Italian Organized Crime Disponível em:< http://www.fbi.gov/hq/cid/orgcrime/lcnindex.htm> Acesso em: 20/03/2010.
} 
atividades criminosas diferentes, de diversos grupos que têm sede na Itália e nos Estados Unidos. Esta organização representa uma das maiores ameaças do crime organizado mundial. É formada por uma aliança de criminosos, ligados por laços de sangue ou por meio de conspiração, dedicada a praticar o crime e proteger seus membros. ${ }^{54}$

Este grupo está ligado a atividades ilegais como: assassinato, extorsão, tráfico de drogas, corrupção de funcionários públicos, jogos de azar, infiltração em empresas legítimas, extorsão de trabalho, agiotagem, prostituição, pornografia, esquemas de fraude fiscal e manipulação de imagens.

Um dos chefes de destaque dessa organização foi Vito Genovese, cuja família já foi considerada a mais poderosa do crime organizado nos Estados Unidos, que além de estarem envolvidos em diversos crimes, citados acima, também se envolveram na manipulação do mercado de ações e outras fraudes. As origens dessa família estão em grupos de criminosos italianos que se instalaram em Nova York, controlados por Joseph Masseria em 1920.

Um marco importante na história do crime organizado italiano e um passo importante no seu processo de expansão foram durante a Segunda Guerra Mundial, com a chegada dos aliados na Sicília, em julho de 1943. Sob o fascismo de Mussolini, a máfia siciliana foi duramente combatida, pois não interessava e não convinha ao regime ter concorrência com outro poder, ainda mais fora do seu controle, não importava se fosse formal ou informal, ou seu campo de atuação. "Como regime autoritário e centralizador, o fascismo não podia tolerar a máfia: pretendia o monopólio da violência e não aceitava qualquer forma de intermediação política" ${ }^{55} \mathrm{O}$ sul da Itália sofreu bastante com a Segunda Guerra Mundial, que bloqueou a migração rumo ao norte por excesso de mão-de-obra, além de proporcionar a reemersão da Máfia na Sicília, à medida que o vazio de liderança local era ocupado por

\footnotetext{
${ }^{54}$ Italian Organized Crime Disponível em:< http://www.fbi.gov/hq/cid/orgcrime/lcnindex.htm> Acesso em: 20/03/2010.

${ }_{55}$ FERRO, Ana Luiza Almeida. Crime Organizado e Organizações Criminosas mundiais. Curitiba: Editora Juruá, 2009. p. 92.
} 
antigos chefes mafiosos, que eram respeitadas figuras locais e podiam posar como antifascistas. ${ }^{56}$

Atualmente os maiores escândalos envolvendo, o que poderia se chamar de uma espécie de 'nova máfia', encontram-se na conexão estrutural ou funcional com o poder público, a corrupção e a infiltração no mundo dos negócios e das concorrências públicas. O comportamento do mafioso mudou um pouco, desde a sua criação aos dias de hoje. De acordo com Howard Abadinsky

\footnotetext{
"o comportamento do velho mafioso tinha o poder - rispetto - como seu objetivo primário. Contudo, o moderno mafioso é um materialista para quem o poder é simplesmente um meio de conseguir riqueza, e transpira conspícuo consumo. O novo mafioso não está preso pelas tradições da cosca rural. Ele se traja como um bem-sucedido homem de negócios." ${ }^{37}$
}

\section{3 - Brasil}

Na década de 1980 o narcotráfico tinha algumas 'tarefas' definidas, como: a Bolívia e o Peru eram responsáveis pela produção da folha de coca e da pasta base; aos grupos da Colômbia cabia transformar a pasta de coca em cocaína; e os bandos criminosos de países limítrofes, tinham a responsabilidade de estabelecer contatos para que a droga chegasse ao seu mercado consumidor principal, Estados Unidos e Europa.

A partir da década de 1990 o panorama começa a ficar diferente, e um novo 'ator' começa a entrar no jogo, que é o Brasil. Devido às suas extensas fronteiras, portos nacionais pouco vigiados, o país torna-se atrativo para esse 'negócio'.

Há uma grande 'integração' entre os criminosos dos países latinoamericanos para o narcotráfico. Países do Caribe servem de trânsito por onde passa grande parte da droga que vai para os Estados Unidos. Nessa etapa do processo, entra fortemente o Brasil, servindo como grande

\footnotetext{
${ }^{56}$ Ibidem, p. 94.

${ }^{57}$ ABADINSKY, Howard. Apud: Ibidem, p. 95.
} 
'corredor' da droga, que sai dos países produtores e vai para os países mais consumidores.

Até a década de 1980, o Brasil era o único país na América do Sul a produzir éter e acetona em escala industrial, produtos utilizados para o processamento da cocaína. Contando com o apoio e vigilância da Drug Enforcement Administration (DEA) ${ }^{58}$, a grande preocupação era controlar as exportações, com isso parte da cocaína consumida no Brasil, passou a ser processada internamente. ${ }^{59}$

No Brasil, o foco maior das atividades para combater o narcotráfico é nas cidades grandes, como Rio de Janeiro, São Paulo, Recife, Belo Horizonte, Brasília, Belém, Fortaleza, Porto Velho, Manaus, Salvador e Curitiba. Realmente nessas cidades há um fluxo maior de tráfico de drogas, lavagem de dinheiro e contrabandistas, no entanto os agentes do crime buscam rotas alternativas para realizarem a logística da droga, e uma rota que é utilizada hoje, pode não ser mais amanhã, e futuramente volta a ser usada, pois os traficantes mudam as técnicas rapidamente, de acordo com a vigilância se está maior ou não em determinada região, ou das próprias estratégias do tráfico.

Segundo Argemiro Procópio, uma das causas da expansão do tráfico, da produção e do consumo no interior do país, deve-se ao fato de falhas na política antidrogas adotada pelo Estado brasileiro, pois seguindo fortemente às pressões e os ditames do DEA. "Assim, os esforços nacionais contra as drogas centraram-se quase que somente nos grande portos marítimos e aeroportos, evitando a saída das drogas para o exterior, ou seja, para os Estados Unidos da América e para Europa Ocidental." ${ }^{00}$

De acordo com uma pesquisa realizada pelo Ministério da Justiça juntamente com o Programa das Nações Unidas para o Desenvolvimento (PNUD), mostra que a demanda de drogas no Brasil,

\footnotetext{
${ }^{58}$ DEA: Força Administrativa de Narcóticos, é um órgão da polícia federal do Departamento de Justiça dos Estados Unidos, encarregado da repressão e controle de narcóticos.

${ }^{59}$ PROCÓPIO, Argemiro. O Brasil no Mundo das Drogas. Petrópolis: Editora Vozes, 1999. p. 19.

${ }^{60}$ Ibidem, p.25.
} 
"indica a cannabis (ou maconha) como a droga ilícita mais consumida no País, com $8,8 \%$ de consumidores (uso em vida), tendo havido um crescimento em relação a 2001, quando se apurou um índice de 6,9\% de uso em vida. No caso da cocaína, em 2005, identificou-se o percentual de $2,9 \%$ de uso em vida, que também foi superior a 2001, quando este alcançou $2,3 \%{ }^{\prime 61}$

O país também tem organizações criminosas de forte atuação, e desempenham vários papéis, não só relacionados ao crime, como na comunidade (favela) em que vivem, algo parecido com o que acontece na Colômbia, conforme citado anteriormente, assumindo papéis de serviço social, coordenando festividades, prestando assistência aos presos e familiares. Esses grupos são: o Comando Vermelho (CV), cuja área de atuação é no Estado do Rio de Janeiro e o Primeiro Comando da Capital (PCC), articulado principalmente no Estado de São Paulo.

Para Carlos Amorin, tanto o CV quanto o PCC possuem uma origem comum:

\begin{abstract}
"emergem no processo de desumanização característico das penitenciárias brasileiras que agregam todos os elementos que possibilitaram o surgimento desses grupos (e de vários outros também, embora de menor expressão). Inicialmente, utilizando o lema 'Paz, Justiça e Liberdade', alguns indivíduos de certa capacidade organizacional e com liderança interna dentro das penitenciárias iniciaram a consolidação das organizações" ${ }^{62}$
\end{abstract}

O Comando Vermelho, provavelmente a maior organização criminosa no Brasil, "tem sua origem no encarceramento de presos políticos, durante 0 regime militar, no fim da década de 60 , e de presos comuns, no presídio da Ilha Grande - demolido em 1994 - no Rio de Janeiro."63 Esse contato carcerário os permitiu trocarem lições de organização, disciplina, lealdade,

\footnotetext{
${ }^{61}$ Relatório de Pesquisa "Tráfico de Drogas e Constituição". Disponível em: $<$ http://www.pauloteixeira13.com.br/arquivos/Sumario executivo pesquisa.pdf $>$ Acesso em: $19 / 03 / 2010$.

${ }^{62}$ AMORIN, Carlos. CV-PCC: a irmandade do crime. Rio de Janeiro: Record, 2006. Apud: BRANDÃO, Thadeu de Sousa. Organizações Criminosas no Brasil: Uma análise a partir da teoria das elites e da teoria da ação coletiva. Revista Eletrônica Inter-Legere, no3 (juldez/2008). Disponível em:

$<$ http://www.cchla.ufrn.br/interlegere/revista/pdf/3/es06.pdf > Acesso em: 20/03/2010

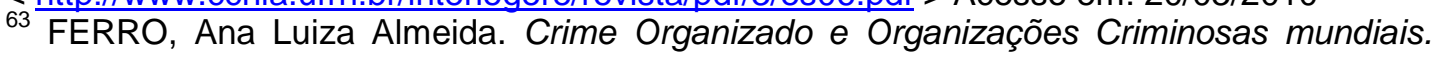
Curitiba: Editora Juruá, 2009. p. 101.
} 
enfrentamento do sistema estatal e métodos de comunicação e codificação de informações. "A verdade é que o Comando Vermelho veio a superar tudo - que a luta armada revolucionária obtivera na década de 70 , tanto no aspecto da infra-estrutura como da disciplina e organização internas". ${ }^{64}$

O Primeiro Comando da Capital (PCC) foi fundado em 1993 no presídio Casa de Custódia de Taubaté, no estado de São Paulo, considerada a mais segura do Estado.

"Alguns detentos resolveram se unir num pacto de solidariedade e com o objetivo de lutar contra as más condições do sistema prisional, formando a organização. Firmaram-se como resistentes e maiores opositores do massacre do Carandiru, no ano de 1992, que deixou 111 mortos no Pavilhão 9."165

Suas principais ações eram sequestros e assaltos à mão armada, no entanto, o tráfico de drogas mostrou-se um negócio muito mais rentável, e o grupo entrou para esse tipo de atividade definitivamente. Teve como líder Marcos Willians Herbas Camacho, conhecido como Marcola.

Esses grupos mantêm sua rede de contatos até mesmo dentro do presídio, através do uso de celulares, assim conseguem coordenar e manter o bom andamento da organização. A atuação de organizações como essas também acabam culminando em rebeliões, principalmente no Estado de São Paulo. Como a que aconteceu em 2006:

"Essas rebeliões, além de se apresentarem como fruto de exigências imediatistas, tiveram também um objetivo político estrategicamente posto: desarticular e desacreditar o Estado enquanto instituição capaz de manter o monopólio do uso exclusivo da força, e por isto, enquanto mantenedor da ordem e da segurança jurídica". ${ }^{6}$

\footnotetext{
${ }^{64}$ Ibidem, p. 101.

${ }^{65}$ FORT, Mônica Cristine. Medo e horror na cobertura jornalística dos ataques do PCC em São Paulo. Disponível em:< http://www.logos.uerj.br/PDFS/26/11 MONICA FORT.pdf $>$. Acesso em: 24/03/2010.

${ }^{66}$ BRANDÃO, Thadeu de Sousa. Organizações Criminosas no Brasil: Uma análise a partir da teoria das elites e da teoria da ação coletiva. Revista Eletrônica Inter-Legere, no3 (juldez/2008). Disponível em:

$<$ http://www.cchla.ufrn.br/interlegere/revista/pdf/3/es06.pdf > Acesso em: 20/03/2010.
} 


\section{4 - Estatísticas das drogas ${ }^{67}$}

Segundo o Relatório Mundial Sobre Drogas - 2009, organizado pelo Escritório das Nações Unidas sobre Drogas e Crimes (UNODC, sigla em inglês), traz evidências que o cultivo das drogas (ópio e coca) está estável ou em declínio. Durante o ano de 2008, foi observado reduções importantes na produção de heroína e cocaína.

Contando com a colaboração dos Estados, o UNODC desenvolve pesquisas anuais sobre plantações nos países que produzem essas drogas em grande quantidade. $O$ resultado de tais pesquisas é que, houve uma redução de $19 \%$ no cultivo da papoula no Afeganistão e uma redução de $18 \%$ no cultivo de coca na Colômbia.

Os índices de produção de outros tipos de droga são mais difíceis de serem rastreados, como também é difícil mensurar o uso das drogas. De acordo com a pesquisa, o uso da maconha em regiões da América do Norte, Europa Ocidental e Oceania, está diminuindo. O uso da cocaína na América do Norte, maior consumidor mundial, sofreu uma redução, enquanto que os índices na Europa permaneceram estáveis.

Um dado preocupante é o aumento no consumo de drogas do tipo estimulantes, como a anfetamina (ATS) ${ }^{68}$, cerca de $30 \%$ das apreensões globais em 2007 foram realizadas no Oriente Próximo e no Oriente Médio, onde o uso de anfetaminas pode ser considerado significativo.

\subsection{1 - Produção}

Opiáceos: Em 2008 a área total de cultivo da papoula nos principais países produtores diminuiu para 189,000 hectares (ha), isto representa uma queda de $16 \%$ em relação a 2007 , e a principal queda observa-se no Afeganistão. Mianmar reportou 28.500 ha de cultivo da papoula. No

\footnotetext{
${ }^{67}$ Os dados estatísticos constantes neste ponto, foram retirados do Relatório Mundial sobre Drogas, do Escritório das Nações Unidas sobre Drogas e Crimes. Disponível em: $<$ http://www.unodc.org/unodc/data-and-analysis/WDR.html >. Acesso em: 15/03/2010.

68 O termo "estimulantes do tipo das anfetaminas (ATS)" utiliza-se para designar tanto as anfetaminas como as drogas do grupo do ecstasy. Anfetaminas é um termo genérico utilizado para descrever várias drogas quimicamente relacionadas entre si que estimulam o sistema nervoso central, sendo as anfetaminas e as metanfetaminas as mais importantes. Disponível em: <http://ar2005.emcdda.europa.eu/pt/page033-pt.html>. Acesso em: $18 / 03 / 2010$
} 
Paquistão cerca de 2.000 ha de papoula foram cultivados, na região de fronteira com o Afeganistão, mantendo os mesmos índices dos últimos cinco anos. A produção de ópio foi estimada em 7.700 toneladas, no Afeganistão, acredita-se que $60 \%$ dessa produção tenha sido transformada em morfina e heroína no país. O Afeganistão exportou aproximadamente 630 toneladas de morfina e heroína, e quase $40 \%$ da produção foi exportada como ópio.

Cocaína: Foi observado um pequeno aumento na Bolívia (6\%) e no Peru (4\%), mas a área total global do cultivo da coca diminuiu $8 \%$ em 2008 , isso devido à uma redução considerável na Colômbia de $18 \%$. Mesmo com essa redução, a Colômbia representa o principal produtor de coca do mundo, com 81.000 ha, ficando à frente do Peru, com 56.100 ha e da Bolívia, com 30.500 ha. Estima-se que a produção global de cocaína tenha caído em 15\%, essa redução deve-se a uma grande queda na produção de cocaína na Colômbia (28\%), que não foi compensada pelos aumentos apresentados na Bolívia e no Peru.

Maconha: Mesurar a produção mundial de maconha é bem mais complicado, já que é produzida em um grande número de países, e pode ser produzida tanto em locais fechados quanto abertos. Estima-se que a produção total de maconha varie entre 13.300 e 66.100 toneladas, e a de haxixe varie entre 2.200 e 9.900 toneladas.

ATS: Estimulantes tipo anfetamina, assim como a maconha, podem ser produzidos em qualquer lugar, e a um custo relativamente baixo. Em 2007 o UNODC estima que foram produzidas entre 231 e 667 toneladas de substâncias do grupo anfetaminas ${ }^{69}$, e entre 72 e 136 toneladas do grupo ecstasy $^{70}$.

\subsection{2 - Consumo}

\footnotetext{
69 "As substâncias do grupo anfetaminas incluem predominantemente a metanfetamina e a anfetamina, mas também incluem substâncias não especificadas desse grupo (por exemplo, comprimidos vendidos como Captagon, metcatinona, fenetilina, metilfenidato entre outros), excluindo as substâncias que pertençam ao grupo ecstasy."

70 "As substâncias do grupo ecstasy incluem predominantemente o MDMA, com o MDA e o MDEA/MDE. Porém a limitada capacidade de controle por parte dos Estados-membros frequentemente causa uma confusão a respeito do atual conteúdo dos comprimidos tidos como sendo 'ecstasy'."
} 
O UNODC estima a existência de algo em torno de 18 e 38 milhões de usuários problemáticos, ou seja, usuários recorrentes ou mesmo viciados em drogas, situação que pede uma atuação mais ativa dos Estados na saúde pública e assistencialismo.

Opiáceos: Estima-se que o número de pessoas que usaram opiáceos ao menos uma vez em 2007 varie entre 15 e 20 milhões de pessoas em termos globais. Os níveis mais altos de uso são encontrados ao longo das principais rotas de tráfico, próximas ao Afeganistão. Em termos de tratamento, esse tipo de droga é o mais problemático.

Cocaína: A estimativa de pessoas que usaram cocaína pelo menos uma vez em 2007 varie entre 16 e 21 milhões. O maior mercado ainda continua sendo a América do Norte, seguido pela Europa Ocidental e do Leste e pela América do Sul.

Maconha: Estima-se que o número de pessoas que usaram maconha ao menos uma vez em 2007 varie entre 143 e 190 milhões de pessoas. A maior quantidade de usuários encontra-se na América do Norte e Europa Ocidental.

ATS: O UNODC estima que entre 16 e 51 milhões de pessoas entre 15 e 64 anos usaram substâncias do grupo anfetaminas ao menos uma vez em 2007; a quantidade de pessoas que usaram drogas do grupo ecstasy ao menos uma vez, está estimada entre 12 e 23 milhões pelo mundo.

O uso de drogas injetáveis é uma pauta de extrema importância para os Estados, pois além de englobar o uso da droga em si, entra em questão o aumento de infecções do vírus HIV. Segundo o UNODC, estima-se que entre 11 e 21 milhões de pessoas no planeta usam drogas injetáveis. A maior parte desse grupo estão na China, Estados Unidos, Rússia e Brasil, que somam $45 \%$ do total da população de usuários de drogas injetáveis estimadas no mundo. 


\section{MÉXICO}

Neste terceiro, e último capítulo, será analisado com mais detalhes o México, com enfoque nas atuações de redes criminosas mexicanas; sua economia e relação com os Estados Unidos.

No início da década de 1990, o México foi apontado, pelo Fundo Monetário Internacional (FMI) e Banco Mundial, como o país exemplar do terceiro mundo. O país incorporou o ideário neoliberal, mas ao invés de caminhar para se tornar um país desenvolvido, experimentou uma grande crise econômica em 1994.

Em 1988 Carlos Salinas de Gotari é eleito presidente (1988-1994), e o México mergulha nos princípios neoliberais. As primeiras medidas econômicas de seu governo visavam à supervalorização do câmbio para incentivar as importações, aumento da taxa de juros para atrair os capitais de curto prazo, estabelecimento de vantagens para que empresas transnacionais instalassem suas filiais no país e a privatização muitas empresas estatais. Com isso a inflação diminuiu de $160 \%$ ao ano em 1987 para 8\% em 1993. Entre 1988 e 1993, o Estado recebeu cerca de 21 bilhões de dólares com as privatizações. Diante disso, a dívida externa privada aumentou em 11 bilhões de dólares ao longo de 1993, chegando a um total acumulado de 34,265 bilhões, resultando no aumento dos juros que suforacam as pequenas e médias empresas. ${ }^{71}$

No dia 1 de Janeiro de 1994, ocorre a implantação do $\mathrm{Nafta}^{72}$, em Chiapas, estado mexicano mais pobre, localizado no extremo-sul do país. Neste ano explode a maior crise mexicana dos últimos tempos, conhecida como 'efeito tequila', que com o levante guerrilheiro organizado pelo EZLN (Exército Zapatista de Libertação Nacional), revelaram uma situação diferente da que era mostrada pelo presidente à opinião pública: a realidade

\footnotetext{
${ }^{71}$ FREITAS, Jonas de; BRícIO, Japiassu; AGUIAR, Renato (Trad.). Enciclopédia do Mundo Contemporâneo. São Paulo: Publifolha, 2000. p. 418.

72 O NAFTA é um acordo de liberalização econômica, assinado por Estados Unidos, Canadá e México, tendo o Chile como associado, com proposta de um prazo de 15 anos para eliminação total das barreiras alfandegárias entre os três países. $\mathrm{O}$ acordo é assinado em 1992, mas só entra em vigor em 1994.
} 
era de uma nação com extrema concentração de renda, desigualdades sociais, altos índices de violência e atrasada.

Com o Nafta, esperava-se que o fluxo de imigração de mexicanos para os Estados Unidos diminuiria, fato que não ocorreu, um pouco ocasionado pela crise em 1994, e mesmo depois de passada crise, o México ainda mostrava certa instabilidade em sua economia. Os salários estão menores hoje do que anteriormente ao Tratado, atingindo até mesmo os trabalhadores mais qualificados, e isso está associado, em grande parte, ao abandono pelo Estado de políticas sociais estruturadoras. Cresceu também o trabalho informal e as desigualdades de renda, pois se verificou que as famílias com rendas mais altas tiveram suas fatias aumentadas, ao contrário do que ocorreu com cerca de $90 \%$ da população que perderam participação ou não sentiram nenhuma mudança. ${ }^{73}$

Desde a década de 1960, a maconha era cultivada no México e exportada, mas este tráfico abrangia somente a região da Califórnia e o Kentucky. A heroína começou em pequenas escalas na década de 1970. Mas o grande trunfo veio nos anos 1980, com a formação das organizações criminosas transnacionais, que com a vigilância redobrada em rotas internacionais da América Central e Caribe, exigiu dos criminosos trabalharem em alianças.

A partir da década de 1990, os cartéis mexicanos tiveram um grande crescimento, primeiramente atuando como intermediário para os colombianos, e depois de forma mais independente, passando até mesmo a contrabandear além da cocaína, a heroína, anfetaminas e maconha. ${ }^{74}$ Algumas organizações criminosas mexicanas que se destacam são: o Cartel de Tijuana, Cartel do Golfo, Cartel de Juárez e Cartel de Sinaloa.

\section{1 - Cartel de Tijuana}

\footnotetext{
73 LIMA, Marcos Costa. México e os efeitos perversos da integração: imigração, fragmentação do espaço e concentração de renda. Disponível em:< http://www.revistas.unifacs.br/index.php/rde/article/viewFile/9/64 >. Acesso em: 20/03/2010. ${ }^{74}$ CASTELLS, Manuel. Fim do Milênio. Trad. Klauss Brandini Gerhardt e Roneide Venâncio Majer. São Paulo: Paz e Terra, 1999. p. 229
} 
Este cartel iniciou-se com a Organização Arellano Félix (AFO, em inglês) desde a década de 1980, foi uma das redes mais poderosas e agressivas do tráfico de drogas no México. Com grandes estruturas em Tijuana e Mexicali, a AFO organiza o transporte, importação e distribuição de toneladas de cocaína e maconha, e também grande quantidade de heroína e metanfetamina nos Estados Unidos. ${ }^{75}$

Nos anos 1990 a AFO transformou a cidade de Tijuana em território livre, para o uso de vários cartéis mexicanos de drogas. De acordo com o jornal mexicano La Crónica, a AFO estabeleceu um sistema de taxas a serem cobrados de outros grupos criminosos para permitirem sua atuação na fronteira da Baja California, e foi o que aconteceu com as Organizações de Chihuahua, Sinaloa, Colima, Tamaulipas, Jalisco, Michoacán e Oaxaca. O sistema de "pedágio" criado pela AFO se transformou numa fonte de diversas guerras entre gangues, nos anos 1990, quando estavam emergindo diversas redes de tráfico de drogas, incluindo a Organização Zambada, que se recusou a pagar as referidas taxas. ${ }^{76}$

A influência do cartel de Tijuana foi além das fronteiras mexicanas, pois se relacionava com organizações criminosas da Colômbia e Peru; com grupos sediados em países da América Central (fundamentais para o transporte da droga dos países produtores até o México); também desenvolveu contato com o crime organizado russo e até mesmo com as FARC (Forças Armadas Revolucionárias da Colômbia).

A marca deste Cartel era o alto grau de violência, intimidação e corrupção, pois com isso, desenvolveram um aparato de segurança interna para garantir não só a lealdade dos companheiros da própria $\mathrm{AFO}$, mas também para assegurar $\mathrm{O}$ bom andamento das relações com as organizações criminosas que atuavam na área comandada pelo Cartel. A

\footnotetext{
${ }^{75}$ MIRÓ, Ramón J. Organized Crime and Terrorist Activity in Mexico, 1999-2002. Disponível em: <http://www.loc.gov/rr/frd/pdf-files/OrgCrime Mexico.pdf> Acesso em: 02/03/2010.

${ }^{76}$ MIRÓ, Ramón J. Organized Crime and Terrorist Activity in Mexico, 1999-2002. Disponível em: <http://www.loc.gov/rr/frd/pdf-files/OrgCrime Mexico.pdf> Acesso em: 02/03/2010.
} 
AFO foi associada a diversos assassinatos de informantes, oficiais da lei mexicanos, traficantes rivais e civis inocentes. ${ }^{77}$

No ano de 2002 a situação muda um pouco. A Organização passa a sofrer muitos ataques de traficantes de redes rivais, sendo o mais notório o assassinato brutal de um de seus grandes líderes, Ramón Arellano Felix, em 10 de fevereiro de 2002, e a prisão de Benjamin Arellano Felix, em 9 de março de 2002. Segundo o procurador-geral mexicano, Rafael Macedo de la Concha, mais de 2.000 filiados foram presos num período de 18 meses. Após a perda dos dois importantes líderes, a Organização passa por uma fase complicada para manter o controle do corredor de drogas de Tijuana, a rede de distribuição nos Estados Unidos, seus fornecedores e o esquema de lavagem de dinheiro. A nova liderança ficou a cargo dos irmãos Francisco Javier Arellano Felix (conhecido como El Tigrillo), Eduardo Arellano Felix e Enedina Arellano Felix, que demonstraram uma tendência menos violenta e mais inteligente para dirigir a Organização. ${ }^{78}$

Nos últimos anos, os grandes cartéis têm formado alianças entre si. 0 Cartel de Tijuana formou aliança com o Cartel do Golfo, após a captura de seus líderes pelas autoridades. Outros cartéis formaram uma forte aliança que passou a se denominar "A Federação" que é dirigida por representantes dos cartéis de Sinaloa, Juárez e Valência. Apesar de trabalharem juntos, continuam a ser organizações independentes (ver áreas de influência dos cartéis no Anexo 2) $)^{79}$.

\section{2 - Cartel do Golfo}

Os Zetas ${ }^{80}$, atuam como um exército privado. O cartel foi criado por um grupo de tenentes e sub-tenentes que deixaram o exército mexicano (GAFES, Grupo Aeromovil de Fuerzas Especiales), nos anos 1990. Com

\footnotetext{
${ }^{77}$ MIRÓ, Ramón J. Organized Crime and Terrorist Activity in Mexico, 1999-2002. Disponível em: <http://www.loc.gov/rr/frd/pdf-files/OrgCrime Mexico.pdf> Acesso em: 02/03/2010.

${ }^{78}$ MIRÓ, Ramón J. Organized Crime and Terrorist Activity in Mexico, 1999-2002. Disponível em: <http://www.loc.gov/rr/frd/pdf-files/OrgCrime Mexico.pdf> Acesso em: 02/03/2010.

${ }^{79}$ COOK, Colleen W. Mexico's Drug Cartels. Disponível em:

$<$ http://ftp.fas.org/sgp/crs/row/RL34215.pdf >. Acesso em: 23/03/2010.

${ }_{80}$ Os Zetas, atuavam para o Cartel do Golfo, e posteriormente passaram a ter sua própria organização.
} 
esse conhecimento militar, foram capazes de realizar operações mais complexas e usar armas mais sofisticadas. Apesar da prisão de seu líder, Osiel Cárdenas em 1993, o grupo tenta manter sua forte influência na região de Nuevo Laredo. Segundo especulações, nada confirmado, esses soldados foram treinados nos Estados Unidos. Estima-se que o número de integrantes do cartel esteja na faixa de 31 a 200 pessoas, que inicialmente eram somente soldados das forças especiais, passando depois a integrar também agentes federais, estaduais, polícias locais, como também civis. ${ }^{81}$

Em setembro de 2005, a Secretária de Defesa do Congresso mexicano indicou que os Zetas estavam contratando forças especiais da Guatemala para treinar novos integrantes, pois o número de mexicanos que eram das forças especiais estava diminuindo e o grupo estava tendo dificuldades de atrair membros do exército mexicano. ${ }^{82}$

Este cartel atua no tráfico de armas, sequestro, tráfico de drogas, lavagem de dinheiro e recebe pagamentos de outros cartéis pelo uso de certas rotas do tráfico. Oficiais mexicanos relatam que os Zetas têm se tornado cada vez mais sofisticados, com uma organização em três níveis, com líderes e intermediários que coordenam as forças de atuação com pequenos criminosos para realizarem os trabalhos de rua. $O$ território de forte atuação do Cartel do Golfo fica nas cidades do norte de Matamoros e Nuevo Laredo. Embora inicialmente, eram encontrados principalmente junto da fronteira norte do México, os Zetas agora têm presença no sul, onde o Cartel do Golfo está disputando território que era controlado pelos Cartéis de Juárez e Sinaloa. Em julho de 2006, a polícia local do sul do estado de Tabasco, prendeu Mateo Díaz López, o líder dos Zetas. ${ }^{83}$

\section{3 - Cartel de Juárez}

\footnotetext{
${ }^{81}$ COOK, Colleen W. Mexico's Drug Cartels. Disponível em:

$<$ http://ftp.fas.org/sgp/crs/row/RL34215.pdf >. Acesso em: 23/03/2010.

${ }_{82}$ COOK, Colleen W. Mexico's Drug Cartels. Disponível em:

$<$ http://ftp.fas.org/sgp/crs/row/RL34215.pdf >. Acesso em: 23/03/2010.

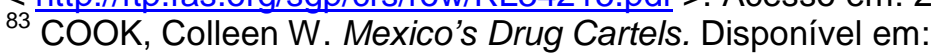

$<$ http://ftp.fas.org/sgp/crs/row/RL34215.pdf >. Acesso em: 23/03/2010.
} 
O Cartel de Juaréz ou Organização Carrillo Fuentes (CFO, em inglês), como o Cartel do Golfo e o Cartel de Tijuana, foi uma poderosa Organização e de grande extensão, tendo suas operações voltadas para o tráfico de drogas. Seu grande líder e um dos fundadores foi Amado Carrillo Fuentes, que apesar de sua morte em julho de 1997, a Organização foi capaz de expandir sua influência nas operações do tráfico, tanto no México quanto nos Estados Unidos, segundo a Unidade Especial Contra o Crime Organizado, do México, a CFO emprega cerca de 3.300 pessoas, distribuídas em 400 células, em 17 estados mexicanos.

O comando do Cartel ficou a cargo de Vicente Carrillo Fuentes ${ }^{84}$, em associação com outros traficantes regionais, que já eram leais antes da morte de Amado. Um importante traficante que ajudou a expandir o território de atuação do Cartel foi Ismael Zambada García (conhecido como El Mayo), através de confrontos com o Cartel de Tijuana. Outro líder importante foi Juan José Esparragoza (conhecido como El Azul), com conexões importantes de fornecedores de cocaína do Peru e da Colômbia. ${ }^{85}$

O Cartel tem forte presença no nordeste do México, incluindo cidades como Ciudad Juárez e Reynosa. A proximidade dessas cidades com os Estados Unidos os mantém próximos das operações de travessia da droga de um país para o outro, pois são responsáveis pelo transporte de toneladas de cocaína, heroína e maconha para os Estados Unidos. Essa região é muito perigosa, tanto que, em outubro de 2000 , de acordo com o jornal americano Washington Times, o Cartel estava oferecendo a recompensa de 200.000 dólares pelo assassinato de agentes do DEA (Drug Enforcement Administration) ${ }^{86}$

\section{4 - Cartel de Sinaloa}

\footnotetext{
${ }^{84}$ Vicente Carrillo Fuentes foi preso pela Polícia Federal Mexicana no dia 02 de abril de 2009, na Cidade do México.

${ }^{85}$ MIRÓ, Ramón J. Organized Crime and Terrorist Activity in Mexico, 1999-2002. Disponível em: <http://www.loc.gov/rr/frd/pdf-files/OrgCrime Mexico.pdf> Acesso em: 02/03/2010.

${ }^{86}$ MIRÓ, Ramón J. Organized Crime and Terrorist Activity in Mexico, 1999-2002. Disponível em: <http://www.loc.gov/rr/frd/pdf-files/OrgCrime Mexico.pdf> Acesso em: 02/03/2010.
} 
O Cartel de Sinaloa, ou Organização Guzmán-Palma, atua fortemente no tráfico de drogas e suas bases estão nos estados de Sinaloa e Jalisco. Em meados do ano 2001, o Cartel tem sofrido reduções na área de atuação e componentes, devido a uma forte guerra de gangues com o Cartel de Tijuana, mas mesmo com agressiva intimidação, o Cartel de Sinaloa tem conseguido se recuperar, apesar da prisão de importantes líderes, o Catel tem mantido sua atuação em 20 estados mexicanos. ${ }^{87}$

Uma forma de demonstrar sua habilidade no crime e na corrupção de funcionários públicos, um de seus líderes Joaquím Guzmán Loera ${ }^{88}$ (conhecido como El Chapo), escapou da prisão mexicana, em janeiro de 2000, onde cumpria pena de 40 anos por tráfico de drogas.

Uma forma importante de distribuição da droga nos Estados Unidos era feita pelos cartéis colombianos ou suas associações com cartéis mexicanos, que se utilizavam de sua grande rede de imigrantes, tudo estabelecido na base da confiança. ${ }^{89}$ Mas após o desmantelamento dos cartéis colombianos, de Cali e Medellín, os cartéis mexicanos ganham mais espaço e importância, pois de intermediários dos colombianos, as quadrilhas mexicanas assumem grande parte das operações de produção e distribuição de drogas para seu grande vizinho e principal consumidor, os Estados Unidos.

Alguns cartéis usaram como modelo, em sua forma de atuação, o Cartel de Cali, que adotavam a seguinte política:

"evite matanças desnecessárias, seja discreto. Aja calmamente e com eficiência. Compre quem quer que seja necessário: polícia, investigadores, juízes, promotores, funcionários do governo local e federal e caciques do PRI (Partido Revolucionário Institucional), de preferência os grandes. Cada dólar investido na corrupção é sinônimo de lucro certo porque estabelece uma rede que, ao se

\footnotetext{
${ }^{87}$ MIRÓ, Ramón J. Organized Crime and Terrorist Activity in Mexico, 1999-2002. Disponível em: <http://www.loc.gov/rr/frd/pdf-files/OrgCrime Mexico.pdf> Acesso em: 02/03/2010.

${ }^{88}$ Joaquím Guzmán Loera está na lista da revista Americana Forbes, como um dos maiores bilionários do mundo. Segundo a revista, Loera possui uma fortuna avaliada em 1 bilhão de dólares.

89 CASTELLS, Manuel. Fim do Milênio. Trad. Klaus Brandini Gerhardt e Roneide Venâncio Majer. São Paulo: Editora Paz e Terra, 1999. p.229.
} 
estender, multiplica as formas de proteção e garante o silêncio."

Com o crescimento do comércio nas fronteiras do México e Estadas Unidos, houve um aumentou no número de passageiros por via terrestre e tráfego de veículos comerciais, e que com isso o tráfico de drogas pode ser mais facilmente ocultado. De acordo com o U.S. Department of Trasnportation (Departamento de Trasnporte dos Estados Unidos) o número anual de viagens de caminhão do México para os Estados Unidos cresceram em 2,8 milhões em 1994 para 4,3 milhões em 2001. ${ }^{91}$

As redes criminosas que estavam atuando na fronteira, se aproveitando da tendência de expansão do comércio, passaram a sofrer mais interferência das autoridades locais, diante de um clima político hostil. No ano 2000, o sistema político mexicano sofreu uma transformação considerável, com a eleição do presidente Vicente Fox Quesada (primeiro líder da oposição eleito desde a Revolução Mexicana), que lançou um projeto de ação contra o crime organizado chamado de 'guerra sem piedade'. Com esse projeto, nos dois anos seguintes o resultado foi a captura, ou morte, de dezenas de chefões de alto escalão, das maiores organizações do tráfico, bem como o desmantelamento de dezenas de redes criminosas que atuavam dentro do governo, militares e agências de aplicação da lei. ${ }^{92}$

Com os ataques terroristas de 11 de setembro de 2001, os Estados Unidos mudaram suas políticas fronteiriças, impondo controles mais rigorosos, gerando um declínio no tráfico de veículos nas fronteiras e com isso uma mudança na atuação das organizações criminosas do tráfico de drogas e contrabando de imigrantes. Como o risco aumentou bastante, essas organizações passaram a recorrer a métodos mais sofisticados de

\footnotetext{
${ }^{90}$ Idem. O Poder da Identidade. Trad. Klaus Brandini Gerhardt. São Paulo: Editora Paz e Terra, 2002. p. 329.

${ }^{91}$ MIRÓ, Ramón J. Organized Crime and Terrorist Activity in Mexico, 1999-2002. Disponível em: <http://www.loc.gov/rr/frd/pdf-files/OrgCrime Mexico.pdf> Acesso em: 02/03/2010.

${ }_{92}$ MIRÓ, Ramón J. Organized Crime and Terrorist Activity in Mexico, 1999-2002. Disponível em: <http://www.loc.gov/rr/frd/pdf-files/OrgCrime Mexico.pdf> Acesso em: 02/03/2010.
} 
ocultação, como: narco-túneis, conteinerização, múltiplas reembalagens e uso do transporte ferroviário para levar as drogas.

Devido a estes acontecimentos, ocasionou um maior estoque de cocaína e maconha que não foi exportada para os Estados Unidos, então os chefões das redes criminosas passaram a vender mais a grupos de distribuição local, abastecendo uma crescente demanda do mercado interno. O aumento dos controles nas fronteiras acabou estimulando também 0 crescimento de uma droga rentável e com consumo interno em ascensão (principalmente em áreas com grande concentração de resorts): as anfetaminas e o ecstasy. ${ }^{93}$

As organizações criminosas mexicanas são responsáveis por grande parte das drogas (maconha, cocaína, heroína, metanfetamina e anfetamina) que são desembarcadas nos Estados Unidos. Segundo o governo americano, 65\% da cocaína que tem como destino aquele país, vêm através da América Central, tendo o México como corredor. Traficantes colombianos utilizam navios de pesca para o transporte e transferências, em grandes quantidades, da cocaína vinda da Colômbia até a costa oeste do México e, em menor medida, para a península de Yucatán. Posteriormente, as cargas são divididas em pequenas quantidades para serem movidas pela fronteira sudoeste. $^{94}$

Os cartéis mexicanos agora controlam toda a distribuição de cocaína por atacado em todo o oeste e meio-oeste dos Estados Unidos. Em cidades como Chicago, Dallas, Denver, Houston, Los Angeles, Phoenix, San Diego, San Francisco e Seattle. Atualmente esses criminosos controlam a droga desde o momento do contrabando, até o desembarque nos Estados Unidos, como também sua distribuição. ${ }^{95}$

Alguns fatores ajudam na atuação desses criminosos, tais como a corrupção e a penetração em diversos níveis das instituições mexicanas. De

\footnotetext{
${ }^{93}$ MIRÓ, Ramón J. Organized Crime and Terrorist Activity in Mexico, 1999-2002. Disponível em: <http://www.loc.gov/rr/frd/pdf-files/OrgCrime Mexico.pdf> Acesso em: 02/03/2010.

${ }_{94}$ MIRÓ, Ramón J. Organized Crime and Terrorist Activity in Mexico, 1999-2002. Disponível em: <http://www.loc.gov/rr/frd/pdf-files/OrgCrime Mexico.pdf> Acesso em: 02/03/2010.

${ }_{95}$ MIRÓ, Ramón J. Organized Crime and Terrorist Activity in Mexico, 1999-2002. Disponível em: <http://www.loc.gov/rr/frd/pdf-files/OrgCrime Mexico.pdf> Acesso em: 02/03/2010
} 
acordo com o Governo dos Estados Unidos, estimativas indicam que cerca de um milhão de dólares são pagos por semana a agentes do governo federal e estadual mexicano e autoridades locais, tudo isso para manter ativo o fluxo de passagem das drogas nas fronteiras.

De janeiro de 2000 a setembro de 2006, o governo mexicano prendeu mais de 79.000 pessoas por acusações relacionadas ao tráfico de drogas. Desse número 78.831 são traficantes de baixo escalão, 15 líderes de cartel, 74 tenentes, 53 agentes financeiros e 428 assassinos de aluguel. Em agosto de 2006, o DEA e a Guarda Costeira dos Estados Unidos, prenderam o líder do Cartel de Tijuana, Francisco Javier Arellano Felix, juntamente com outros líderes, em um barco na costa mexicana. Seu irmão, Francisco Rafael Arellano Felix, foi extraditado para os Estados Unidos em setembro de 2006. Em janeiro de 2007, o México extraditou 15 pessoas para os Estados Unidos, incluindo quatro líderes importantes dos cartéis da droga: Osiel Cárdenas Guillén, chefe do Cartel do Golfo; Ismael Higuera Guerrero e Gilberto Higuera Guerrero, do Cartel de Tijuana e Hector Palma Salazar, do Cartel de Sinaloa e líder da aliança "A Federação". ${ }^{6}$

Em março de 2007 o presidente dos Estados Unidos, George W. Bush, e do México, Felipe Calderón, se reuniram na cidade mexicana de Mérida, para discutirem o crime transnacional e a sua contenção, considerando com um dos problemas mais relevantes na relação entre os dois países. Desse encontro resultou um acordo de cooperação, que se deu o nome de Iniciativa Mérida, ou Plano México.

O programa, com perspectiva de duração de três anos, disporia da soma de $\$ 1.5$ bilhões de dólares, para viabilizar ações de combate ao tráfico de drogas e o crime organizado no México e na América Central, devido ao grande aumento da violência causado pelos cartéis de drogas, gangues e outros grupos criminosos. ${ }^{97}$

\footnotetext{
${ }^{96}$ COOK, Colleen W. Mexico's Drug Cartels. Disponível em:

$<$ http://ftp.fas.org/sgp/crs/row/RL34215.pdf >. Acesso em: 23/03/2010.

${ }^{97}$ PEREIRA, Paulo. Estados Unidos e América Latina no governo Obama: estratégias de segurança continental. Disponível em:
} 
A proposta foi aprovada pelo Congresso americano em junho de 2008, e de início foi disponibilizado US\$ 400 milhões para compra de helicópteros, expansão da infra-estrutura de telecomunicação e monitoramento de regiões via satélite, profissionalização do corpo policial e suporte ao avanço em tecnologia para as agências de reforço da lei no país.

O projeto Iniciativa Mérida, além de visar o combate ao tráfico de drogas e armas, também pretende que o México faça um controle mais rígido aos imigrantes que tentarem atravessar a fronteira com os Estados Unidos sem documentos. Apesar de grande patrulhamento feito pela polícia norte-americana, os mexicanos também terão que cuidar de seus compatriotas que se arriscam, como também guatemaltecos, hondurenhos e salvadorenhos, que devem receber tratamento similar aos que os mexicanos padecem nos Estados Unidos. ${ }^{98}$

Todas essas missões determinadas para o México, colocá-las em prática é um grande desafio para o país, que além de ter que lidar com os graves problemas trazidos pelo tráfico de drogas precisa melhorar sua economia, assistência social, diminuir o desemprego (que está muito alto, e a cada ano 1 milhão de jovens buscam o primeiro emprego). É um país em desenvolvimento que precisa urgentemente rever suas linhas de atuação política, às vezes vendo mais o problema interno, sem tamanha interferência dos Estados Unidos, com atitudes mais sérias no combate ao crime, mais punições e táticas de combate a corrupção.

$<$ http://www.allacademic.com//meta/p mla apa research citation/3/8/0/9/7/pages380976/p3 80976-25.php>, acesso em 02/10/2009.

${ }_{98}$ NAVARRO, Luis Hernández. México, polícia dos Estados Unidos. Le Monde Diplomatique Brasil. Disponível em: <http://diplo.uol.com.br/2007-12,a2085> Acesso: 03/10/2009. 


\section{CONCLUSÃO}

Ao escolher este tema, a dúvida inicialmente apontada foi acerca de sua escassa bibliografia e, as poucas fontes disponíveis, nem todas são tão confiáveis. E foi o que se confirmou. Há pouco estudo efetivo sobre o tema, ocorrendo mais meras citações em jornais ou revistas.

A partir desse levantamento foi possível perceber o quanto o assunto do crime organizado transnacional é importante e merece mais análise e pesquisa. Pois o grande fluxo movimentado pelas organizações criminosas é algo que interfere intimamente na economia, na política e no desenvolvimento social dos países, como mostrado na Colômbia e no México.

O tráfico de drogas é um tipo de crime que gera lucros altíssimos, maior inclusive que a renda interna de muitos países, e para analisar esse tipo de contravenção, tem de se levar em conta as dimensões políticas e sociológicas da região, pois o modus operandi das organizações vai variar de acordo com isso.

Neste estudo foram apresentados alguns exemplos de organizações criminosas e, a partir disso, percebe-se o quanto é difícil e delicado o tema, devido sua grande diversidade na forma de atuação, e que envolve uma estrutura complexa para o seu andamento. Desde extorsão, sequestro, suborno e corrupção, são ferramentas fortemente usadas pelos criminosos, para que nada atrapalhe o desempenho e movimentação da organização. Há condutas a serem seguidas, mesmo que não escritas, e quem não as segue devidamente paga um preço alto, muitas vezes com a própria vida.

Com tudo isso, foi possível observar que para uma ação efetiva de combate ao crime, é necessário que os Estados façam alianças com esse fim, pois como o crime ultrapassa as fronteira de um Estado, uma ação conjunta provavelmente renderia melhores resultados. Quem sabe até com coordenação da Organização das Nações Unidas, que já desenvolve um importante trabalho de pesquisa, com análises e estatísticas acerca, como mostrado no segundo capítulo. 
Os Estados Unidos têm demonstrado grande interesse em realizar tais parcerias. Demonstração disso foi o projeto conhecido como Iniciativa Mérida, que provavelmente no fim das contas visava resolver um problema interno, como por exemplo, a diminuição do número de imigrantes latinos em território americano e um combate mais duro ao tráfico de drogas, visto que, o país é um grande consumidor da 'mercadoria' desses cartéis mexicanos e isso gera custos altíssimos para a Casa Branca, tanto com a saúde, como com a segurança pública. 


\section{ANEXOS}

\section{Anexo 1}

Processo de refino da cocafna, indicando também seus subprodutos ${ }^{4}(C)$

\section{FOLHAS DE COCA \\ Erythroxylon coca}

Maceração e tratamento químico com solventes pesados e ácidos.

Pureza: $0,5 \%$ a $2 \%$ de cocaina nas folhas.

Podem ser mascadas.

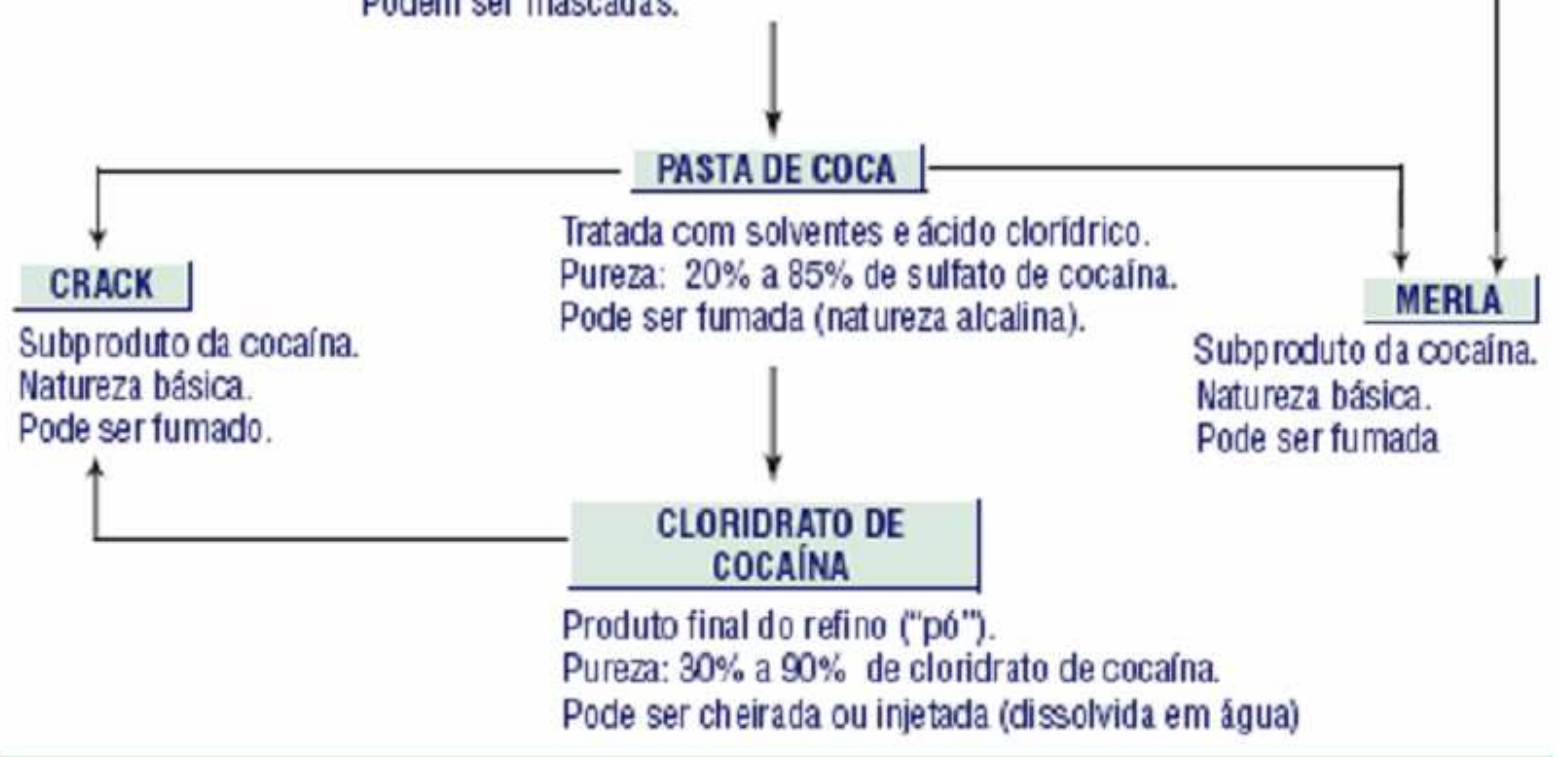

Fonte: http://psicoativas.ufcspa.edu.br/vivavoz/revisoes/cocaina.pdf 
Anexo 2

Figure 2. Mexican Cartel Areas of Influence

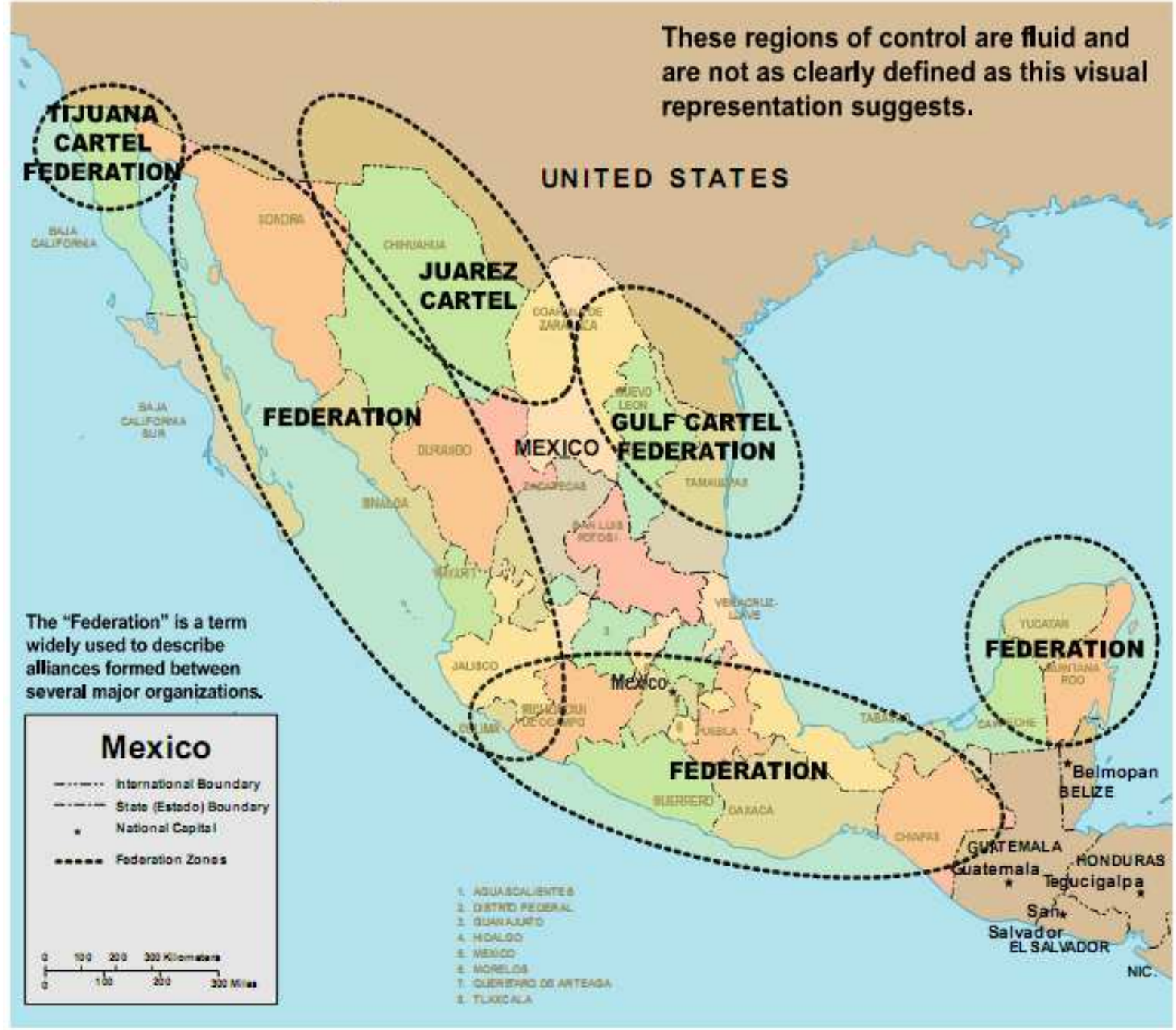

Fonte: U.S. Drug Enforcement Administration (DEA). 


\section{BIBLIOGRAFIA}

BOBBIO, Norberto; MATTEUCCI, Nicola e PASQUINO, Gianfranco. Dicionário de Política. Trad. Carmen C. Varriale [et al.]. $5^{\underline{a}}$ edição. Brasília: Editora Universidade de Brasília; São Paulo: Imprensa Oficial do Estado, 2000.

CASTELLS, Manuel. Fim do Milênio. Trad. Klauss Brandini Gerhardt e Roneide Venâncio Majer. São Paulo: Paz e Terra, 1999.

CASTELLS, Manuel. O Poder da Identidade. Trad. Klaus Brandini Gerhardt. São Paulo: Editora Paz e Terra, 2002.

DIAS, Cláudia Sérvulo da Cunha (coord). Tráfico de Pessoas para Fins de Exploração Sexual. Brasília: OIT, 2005.

FERRO, Ana Luiza Almeida. Crime Organizado e Organizações Criminosas mundiais. Curitiba: Editora Juruá, 2009.

FREITAS, Jonas de; BRÍCIO, Japiassu; AGUIAR, Renato (Trad.). Enciclopédia do Mundo Contemporâneo. São Paulo: Publifolha, 2000.

LUPO, Salvatore. História da Máfia: das origens aos nossos dias. Trad. Álvaro Lorencini. São Paulo: Editora UNESP, 2002.

MINK, Gisele Fernandes Cardoso. Lavagem de Dinheiro. Rio de Janeiro: Universidade Federal do Rio de Janeiro, 2005.

PROCÓPIO, Argemiro. O Brasil no Mundo das Drogas. Petrópolis: Editora Vozes, 1999. 
PROCÓPIO FILHO, Argemiro; VAZ, Alcides Costa. O Brasil no contexto do narcotráfico internacional. In: Revista Brasileira de Política Internacional. Brasília, no 1, 1997.

VILLA, Rafael Duarte, OSTOS, Maria Del Pilar. As relações Colômbia, países vizinhos e Estados Unidos: visões em torno da agenda de segurança. In: Revista Brasileira de Política Internacional. Brasília, ano 48, n.2, jul-dez 2005.

WERNER, Guilherme Cunha. O Crime OrganizadoTransnacional e as Redes Criminosas: Presença e Influência nas Relações Internacionais Contemporâneas. São Paulo: Universidade de São Paulo, 2009.

Internet:

http://www.espacoacademico.com.br/034/34coliveira.htm http://michaelis.uol.com.br/moderno/portugues http://www.pucminas.br/imagedb/conjuntura/CNO ARQ NOTIC2008040909 0002.pdf

https://www.coaf.fazenda.gov.br/conteudo/publicacoes/cartilha-lavagem-dedinheiro-um-problema-mundial/ http://portal.mi.gov.br/main.asp?Team=\%7B9668E5B2\%2D1F9C\%2D4106\% 2DB0E8\%2DF32CB3A0B80E\%7D

http://veja.abril.com.br/educacao/piratas-somalia/piratas-somalia.html http://psicoativas.ufcspa.edu.br/vivavoz/revisoes/cocaina.pdf http://www.brasilescola.com/drogas/heroina.htm http://www.unifesp.br/dpsicobio/cebrid/quest drogas/maconha.htm http://www.pbs.org/wgbh/pages/frontline/shows/drugs/business/inside/colom bian.html http://www.counterpunch.org/brittain08012008.html http://www.consciencia.net/2004/mes/07/farc-40anos.html http://www.fbi.gov/hq/cid/orgcrime/lcnindex.htm 
http://www.pauloteixeira13.com.br/arquivos/Sumario executivo pesquisa.pdf http://www.cchla.ufrn.br/interlegere/revista/pdf/3/es06.pdf http://www.logos.uerj.br/PDFS/26/11 MONICA FORT.pdf http://www.unodc.org/unodc/data-and-analysis/WDR.html http://ar2005.emcdda.europa.eu/pt/page033-pt.html http://www.revistas.unifacs.br/index.php/rde/article/viewFile/9/64 http://www.loc.gov/rr/frd/pdf-files/OrgCrime Mexico.pdf http://ftp.fas.org/sgp/crs/row/RL34215.pdf http://www.allacademic.com//meta/p mla apa research citation/3/8/0/9/7/pa ges380976/p380976-25.php http://diplo.uol.com.br/2007-12,a2085 